José María SAlvador GonZÁlez, Sicut lilium inter spinas. Floral metaphors in late medieval Marian iconography from patristic and theological sources

\title{
Sicut lilium inter spinas. Floral metaphors in late medieval Marian iconography from patristic and theological sources
}

\section{Sicut lilium inter spinas. Metáforas florales en la iconografía mariana bajomedieval a la luz de fuentes patrísticas y teológicas}

\author{
José María SALVADOR GONZÁLEZ \\ Universidad Complutense de Madrid \\ Departamento de Historia del Arte I (Medieval) \\ jmsalvad@ucm.es
}

Recibido: 16/08/2014

Aceptado: 03/09/2014

\begin{abstract}
This paper $^{1}$ proposes an interpretation of the flowers and other plant motifs present in some late medieval images of four Marian themes: the Virgin Enthroned with Child, the Virgin of Humility, the Sacra Conversazione and the Coronation of the Virgin. By supplementing certain unjustified conventions that, without any argument, see these flowers as natural symbols of Mary's love or virginity, our iconographic proposal is based on multiple evidence by prestigious Church Fathers and medieval theologians. By commenting some significant passages of the Old Testament, all of them praise the Mother of the Savior in terms of flowers and plants as metaphors for her holiness and virtue. Thus, on the basis of a solid patristic and theological tradition, this paper attempts to interpret these botanic elements as symbolic figures of purity, humility, charity, sublimity of virtue and absolute holiness of Mary and, as the essential core, her perpetual virginity and virginal divine motherhood.
\end{abstract}

Key Words: Medieval art, iconography, Mariology, Patrology, late medieval painting.

Resumen: El presente artículo propone interpretar las flores y otros motivos vegetales presentes en algunas imágenes bajomedievales de cuatro temas marianos: la Virgen entronizada con Niño, la Virgen de la Humildad, la Sacra Conversazione y la Coronación de la Virgen. Complementando ciertas convenciones injustificadas, que, sin ofrecer argumentos, ven dichas flores como símbolos naturales de la virginidad o del amor de María, nuestra propuesta iconográfica se funda en múltiples testimonios de prestigiosos Padres de la Iglesia y teólogos medievales. Todos ellos, comentando significativos pasajes del Antiguo Testamento, elogian a la Madre del Salvador en términos de flores y plantas como metáforas de su santidad y sus virtudes. Así, basándonos en una sólida tradición patrística y teológica, intentamos interpretar esos elementos vegetales como figuras simbólicas de la pureza, la humildad, la caridad, la excelsitud de virtudes y la santidad absoluta de María y, como núcleo esencial, su virginidad perpetua y su virginal maternidad divina.

Palabras clave: Arte medieval, iconografía, mariología, patrística, pintura bajomedieval.

Summary: 1. Prologue. 2. Harvesting in Marian iconographic themes with floral elements.

\footnotetext{
${ }^{1}$ This article is a product of the research activity that the author develops as Director of the Research Group CAPIRÉ, affiliated to the Department of Art History I (Medieval) at the Complutense University of Madrid, and as a member of the Research Group of the CNPq of Brazil "Art, Philosophy and Literature in the Middle Ages", coordinated by Dr. Ricardo da Costa, Professor Associated III of the Department of Art and Music Theory in the Universidade Federal do Espírito Santo (UFES), Vitoria, Brazil.
} 
José María SALVAdOR GonZÁlez, Sicut lilium inter spinas. Floral metaphors in late medieval Marian iconography from patristic and theological sources

2.1. The Virgin enthroned with Child. 2.2. From the Virgin of Humility to the human Mother. 2.3. The Sacra Conversazione. 2.4. The Coronation of the Virgin. 3. A hermeneutic approach in patristic and theological key. 4. Conclusions. Sources and Bibliography.

$$
* * *
$$

\section{Prologue}

Among the countless artistic images that illustrate the various topics and motifs of the multi-faceted Marian iconography ${ }^{2}$ one finds very frequently some flowers -especially roses and lilies, also known as white lilies or madonna lilies (lilium candidum) - , as well as gardens, hedges, trees and plants of various specific features. Such flowers and plants, in the rare cases of having received special attention from any researcher, have generally been interpreted conventionally as natural symbols of the Virgin Mary's virginity, purity, love, or sanctity.

In our view, these conventional interpretations, even being partially valid, need to be supplemented and enriched with other conceptual elements. In any case, it does not look prudent to shoulder them in an arbitrary manner, because they need to be justified with reliable arguments, extracted from the doctrinal, patristic and theological sources, which make up the solid corpus of Mariology. 3

In tune with this last idea, we have already interpreted in some papers some floral representations as metaphors for Mary in the iconographic themes of the Annunciation and Assumption. Regarding to this last issue, we tried to explain the overflowing sprout of flowers in the Virgin Mary's tomb after her resurrection and assumption to heaven. ${ }^{4}$ At the same time, we believed to be able to explain doctrinally the symbolic presence of the lily in the scenes of the

\footnotetext{
${ }^{2}$ Within the very plentiful bibliography on Marian iconography in general, see, for example, the following studies: Maurice VLOBERG, La Vierge et l'Enfant dans l'art français, Paris, Arthaud, 1954 (1933), 323 pp.; Manuel TRENS, María. Iconografia de la Virgen en el arte español, Madrid, Plus Ultra, 1947, 715 pp.; Timothy Verdon, Maria nell'arte europea (Didascalie a cura di Filippo Rosi), Milano, Electa, 2004, 227 pp.; Marie-Louise THEREL, Le triomphe de la Vierge-Église. Sources historiques, littéraires et iconographiques, Paris, Éditions du CNRS, 1984, 374 pp.; Gertrud SCHILlER, Ikonographie der christlichen Kunst. Band 4,2, Maria, Gütersloh, Gütersloher VerlagHaus, 1980, 472 pp.

${ }^{3}$ For the study of the patristic and theological sources of Mariology see, as very important contribution, the extensive collection of Greek and Latin texts compiled by Sergio ÁLVAREZ CAMpos, Corpus Marianum Patristicum (Continens omnia alicuius momenti de Beata Maria Virgine documenta quae reperiri potuerunt in scriptoribus septem primorum saeculorum. Collegit ex novissimis editionibus et digessit Sergius Alvarez Campos), Burgos, Ediciones Aldecoa, 1970-1981, 7 vols. It is also interesting to note the more restricted study of José Antonio de Aldama, María en la Patrística de los siglos I y II, Madrid, La Editorial Católica, Col. Biblioteca de Autores Cristianos, 1970, 380 pp.

4 José María SALVADOR GONZÁLEZ, "Nardus mea dedit odorem suum. Interpretación iconográfica de La Asunción de María con sepulcro florido en el arte italiano bajomedieval a la luz de fuentes patrísticas y teológicas", De Medio Aevo, no 1, enero-junio 2013, Madrid, Universidad Complutense de Madrid, pp. 67-116.
} 

medieval Marian iconography from patristic and theological sources

Annunciation from the perspective of three biblical quotations: the stem sprung from the Jesse's root ${ }^{5}$ the flowering of the Aaron's dry $\operatorname{rod}^{6}$ and the rhetorical figure of "the flower of the field and the lily of the valleys" in the Song of Songs. ${ }^{7}$

Excluding, therefore, now the images of the Annunciation and Assumption, this article will discuss several other Marian themes and subthemes in which some flowers in the Mary's hands or around her ${ }^{8}$ assume a so essential metaphorical function to the extent of allowing us to interpret in whole or in part their Mariological meanings in those images. We will focus thus our study in four accurate Marian subjects: the Virgin enthroned with Child (a simple version of the Maiestas Mariae), the Virgin of Humility, the Sacra Conversazione and the Virgin Mary's Coronation. To illustrate each of these topics we will discuss iconographically some medieval european paintings -especially from Italy, Spain and Flanders - that include flowers and other botanic elements in its composition.

\section{Harvesting in Marian iconographic themes with floral elements}

\subsection{The Virgin enthroned with Child}

As representative of this first thematic model $-\mathrm{a}$ synthetic version of the Maiestas Mariae - we will analize four paintings by Giotto, Pere Serra, Fra Angelico and Jaume Huguet.

In an effective formula of Marian Maestà, Giotto de Bondone (1267-1337) depicts in his broad altarpiece Madonna Ognissanti, c. 1310, in the Galleria degli Uffizi (Fig. 1) ${ }^{9}$-originally painted for the church of Ognissanti in Florence- a gigantic Virgin majestically enthroned with her child in her arms, while she is surrounded in court of honor by several offering angels, and some saints. Structured in a composition of rigid symmetry, mother and son are crimped as pearls on a throne with canopy, flanked in vertical alignment for the characters of the celestial escort. What is interesting for our purposes in this

\footnotetext{
5 José María SALVADOR GONZÁLEZ, "Flos de radice Iesse. Aproximación hermenéutica al motivo del lirio en la pintura gótica española de La Anunciación a la luz de fuentes patrísticas y teológicas", Eikón / Imago, 4, julio-diciembre 2013, Madrid, Universidad Complutense de Madrid, pp. 183-222.

${ }^{6}$ José María SALVAdor GonZÁLEZ, "In virga Aaron Maria ostendebatur. Nueva interpretación del ramo de lirios en La Anunciación gótica española a la luz de fuentes patrísticas y teológicas", Anales de Historia del Arte, no 24, Universidad Complutense de Madrid, 2014, pp. $37-60$.

${ }^{7}$ José María SALVADOR GONZÁLEZ, "Flos campi et lilium convallium. Tercera interpretación del lirio en la iconografía de La Anunciación en el Trecento italiano a la luz de fuentes patrísticas y teológicas", Eikón Imago, no 5, Universidad Complutense de Madrid, enero-junio 2014, pp. 75-96.

${ }^{8}$ I am grateful to Professor Patricia Grau-Dieckmann for making me to note in the images of some paintings included in this article some details about flowers that had passed unnoticed for me at first glance.

${ }^{9}$ GiotTo, Madonna Ognissanti (Madonna in Maestà), c. 1310, tempera and gold on wood, 325 x $204 \mathrm{~cm}$. Galleria degli Uffizi, Florence.
} 
altarpiece is the set of offerings carried by the four more visible angels. Two of them, standing in the middle area on both sides of the throne, offer to their lady a crown of gold and a coffer of the same metal, offerings that refer to the idea of Mary as Queen of Heaven, to whom the angels, the saints, the prophets, the virgins, the martyrs, the confessors and the other blessed of Paradise serve and pay homage as devout subjects. With even greater salience and visibility, the two angels in white dresses kneeling in the foreground offer to the Madonna snowwhite lilies and white and red roses, which they carry in large golden vases, with symptomatic appearance of a womb.

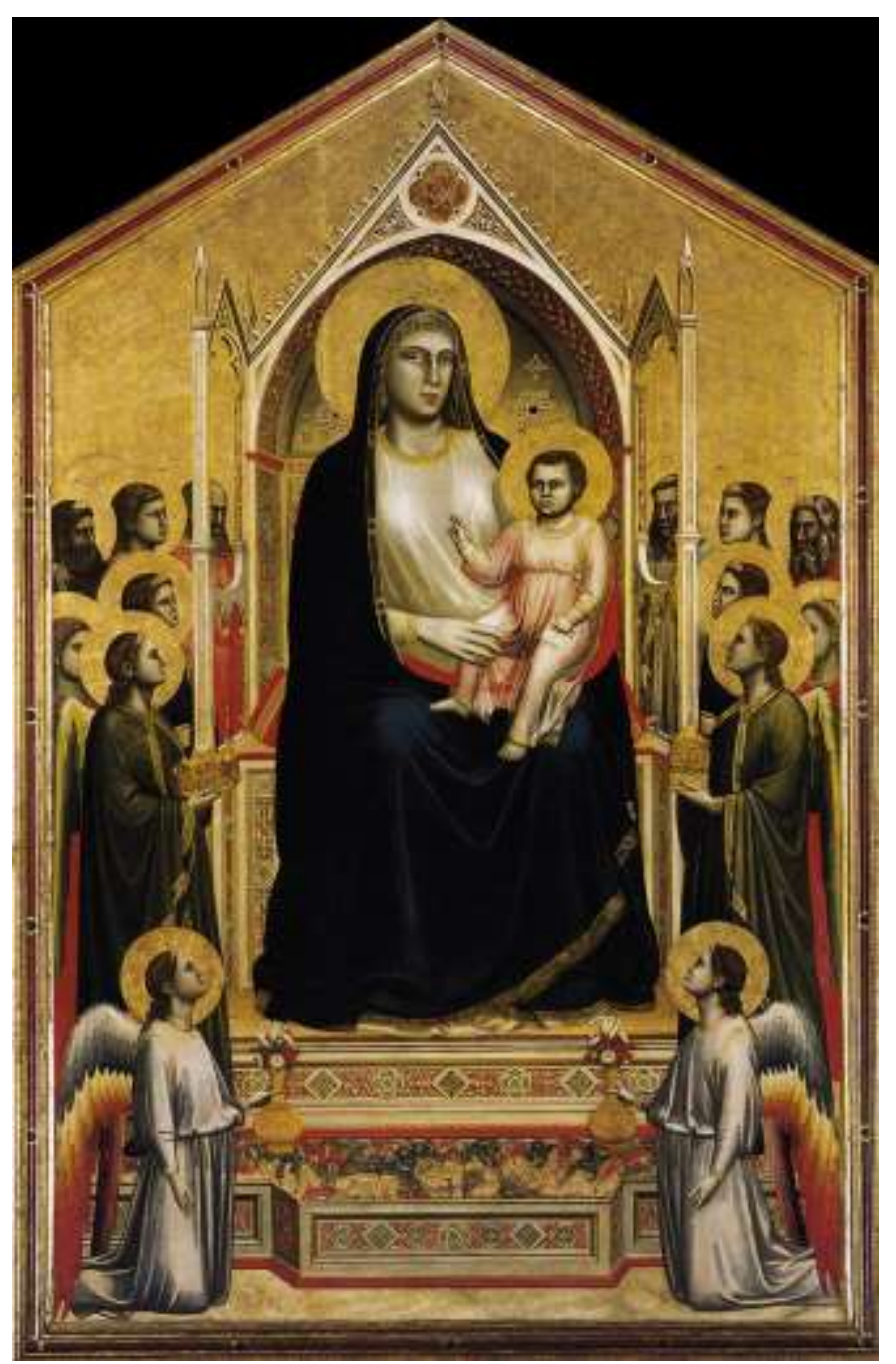

Fig. 1. GiotTo, Madonna Ognissanti (Madonna in Maestà), c. 1310. Galleria degli Uffizi,

Florence. Image from Wikimedia Commons (Last access: 10/08/2014)

The desire to find the precise meaning of these flowers in this scene of Marian Majesty could validate a first superficial interpretation, undoubtedly the most insignificant and incomplete: in full harmony with the other precious offerings (the gold crown and coffer), such flowers suit perfectly as valuable material tributes with which the subjects and courtiers usually demonstrate their allegiance to the kings of this world in their coronation ceremonies or ascension to the throne; and, if this is true for the kings of this world, with greater reason will hold for the Sovereign of Heaven. 

medieval Marian iconography from patristic and theological sources

A second more relevant exegesis would interpret these floral offerings as spiritual tributes, highlighting the Marian bias that, according to some extremely problematic conventions, is assigned to those flowers: the white lilies or madonna lilies as symbols of Mary's purity and virginity; the white and red roses as symbols of her charity and love (the white roses), and her pain and suffering by the Passion of Christ (the red roses).

While this second interpretation is quite acceptable, it needs, however, to be improved by the third multifocal exegesis that, in the light of the patristic and theological tradition, we will propose in the second part of this paper.

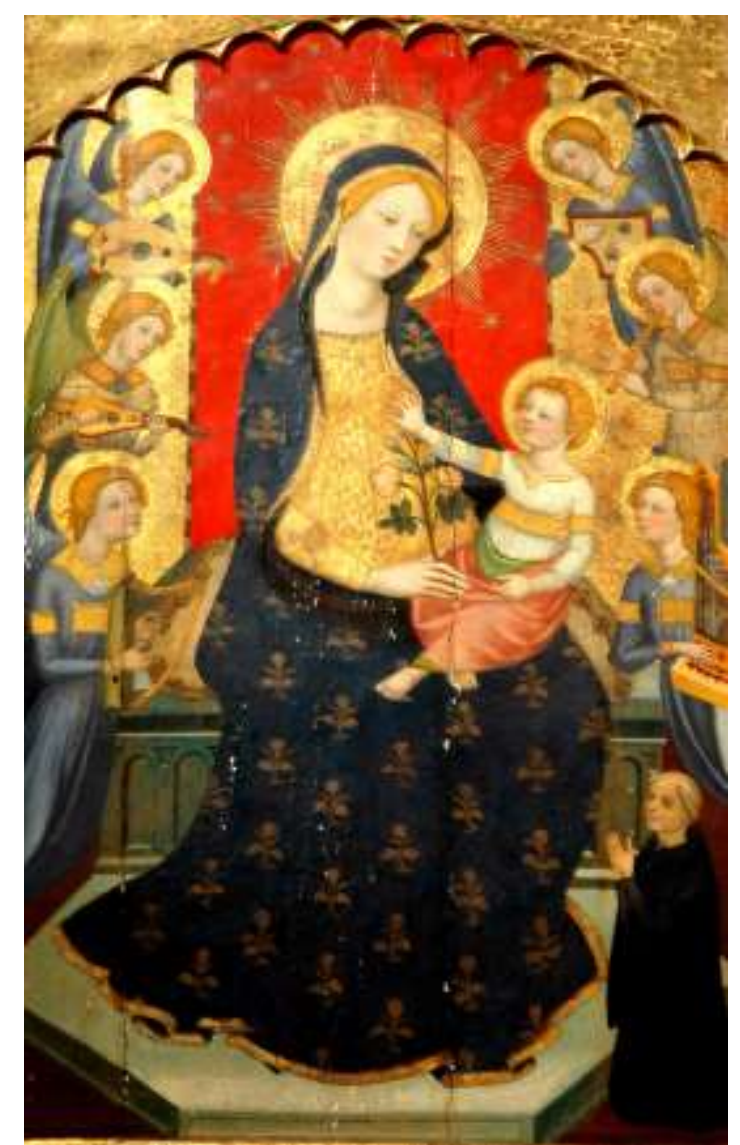

Fig. 2. PERE SERRA, Virgin enthroned with Child, of the Altarpiece of the Monastery of Sant Cugat del Vallés, Barcelona, 1375. Image from Wikimedia Commons (Last access: 10/08/2014)

The Virgin enthroned with Child, 1375 (Fig. 2), central panel of the altarpiece painted by Pere Serra (active 1357-1406) for the Benedictine monastery of Sant Cugat del Vallés (Barcelona), ${ }^{10}$ includes many floral elements of great relevance for our purposes. Symmetrically flanked by a chorus of six musician angels and the kneeling benedictine donor, the extolled Mother of God offers a branch of roses to her child. In addition the Virgin's mantle is fully decorated with patterns of roses in luxurious gold brocade. The interest in finding the meaning of such flowers increases here by the fact that these roses are not gifts to the Mother of Jesus, but attributes that she herself carries -as if they

\footnotetext{
${ }^{10}$ PERE SERRA, Virgin enthroned with Child, central panel of the Altarpiece of the Monastery of Sant Cugat del Vallés, Barcelona, 1375, tempera and gold on wood.
} 

medieval Marian iconography from patristic and theological sources

could be identified with her-, both in reality (those of the branch in her hand) and in image (those embroidered with gold threads in her mantle).

Even if we will give later other explanations on these roses from theological bases, it sounds logical to think that, in the first instance, they refer in this convent altarpiece to the Marian devotion of the rosary. ${ }^{11}$ At last this devotion, emerged already in embryonic form at the beginning of the ninth century, became very popular in its final fashion since the thirteenth century under the impulse of the Dominican friars, to the extent of becoming an usual practice among the simple believers, and in a daily norm between the religious communities, such as the Benedictines resident in the Sant Cugat's monastery. In this order of ideas, the detail that the edges of the cushion on which Mary sits assume the shape of a rosary of thick wood beads is very eloquent.

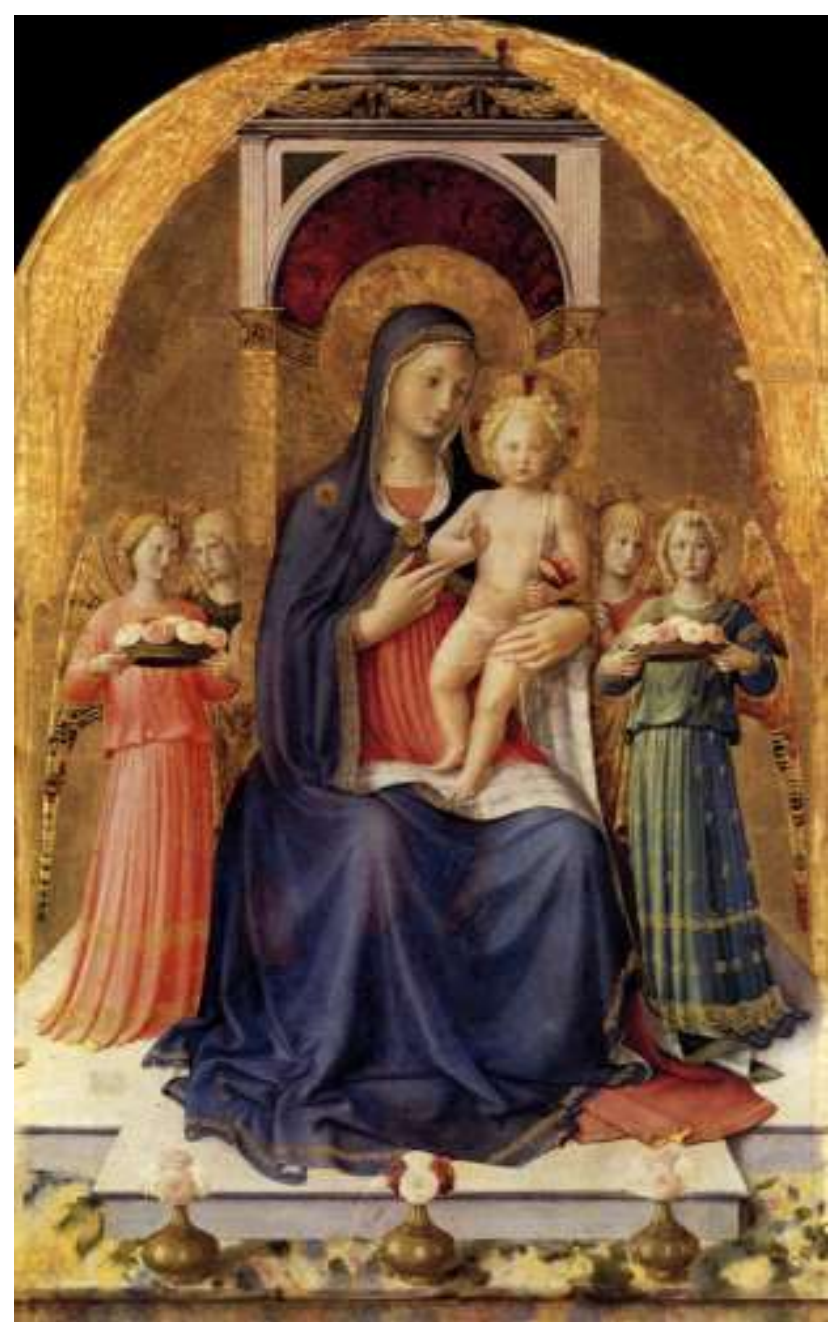

Fig. 3. FrA ANGELICO, Virgin and Child with four angels, central panel of the Perugia Altarpiece, 1447-1448. Galleria Nazionale dell'Umbria, Perugia. Image from Wikimedia Commons (Last access: 14/08/2014)

\footnotetext{
${ }^{11}$ In its final official formula, the complete Rosary consists essentially of the recitation of one hundred and fifty Ave Marias, structured in three series of fifty each, corresponding to the fifteen mysteries of the Virgin: five joyful mysteries, five painful and five glorious. In each mystery, each ten Ave Maria is preceded by a Pater noster and followed by the Gloria Patri.
} 
José María SALVAdOR GonZÁlez, Sicut lilium inter spinas. Floral metaphors in late medieval Marian iconography from patristic and theological sources

Fra Angelico ( 1390-1455), in his Madonna and Child with four angels (Fig. 3 ) of the Perugia Altarpiece (Guidalotti Polyptych) ${ }^{12}$-now preserved for the most part in the Galleria Nazionale dell'Umbria in Perugia ${ }^{13}$-, raises a simplified version of Maiestas Mariae, with the Mother and Child Enthroned under a vaulted canopy before an entourage of four angels that pay tribute of honor to both. For the studied topic two details are very valuable in this panel: first of all, the two angels in the foreground offer to the Sovereign of Heaven two trays filled with white roses; further strengthening this circumstance, three womb-like vases with red and white roses are aligned next to the pedestal of the throne. In this case you can still consider valid all that has been said when analyzing the Giotto's Ognissanti Madonna on the usual interpretation of the white roses as metaphors of Mary's chastity and love, and the red roses as figures of the blood and pain in the Christ's Passion. In spite of this, as it will be seen later, the Church Fathers and theologians will provide some significant keys to deepen and refine these interpretive conventions.

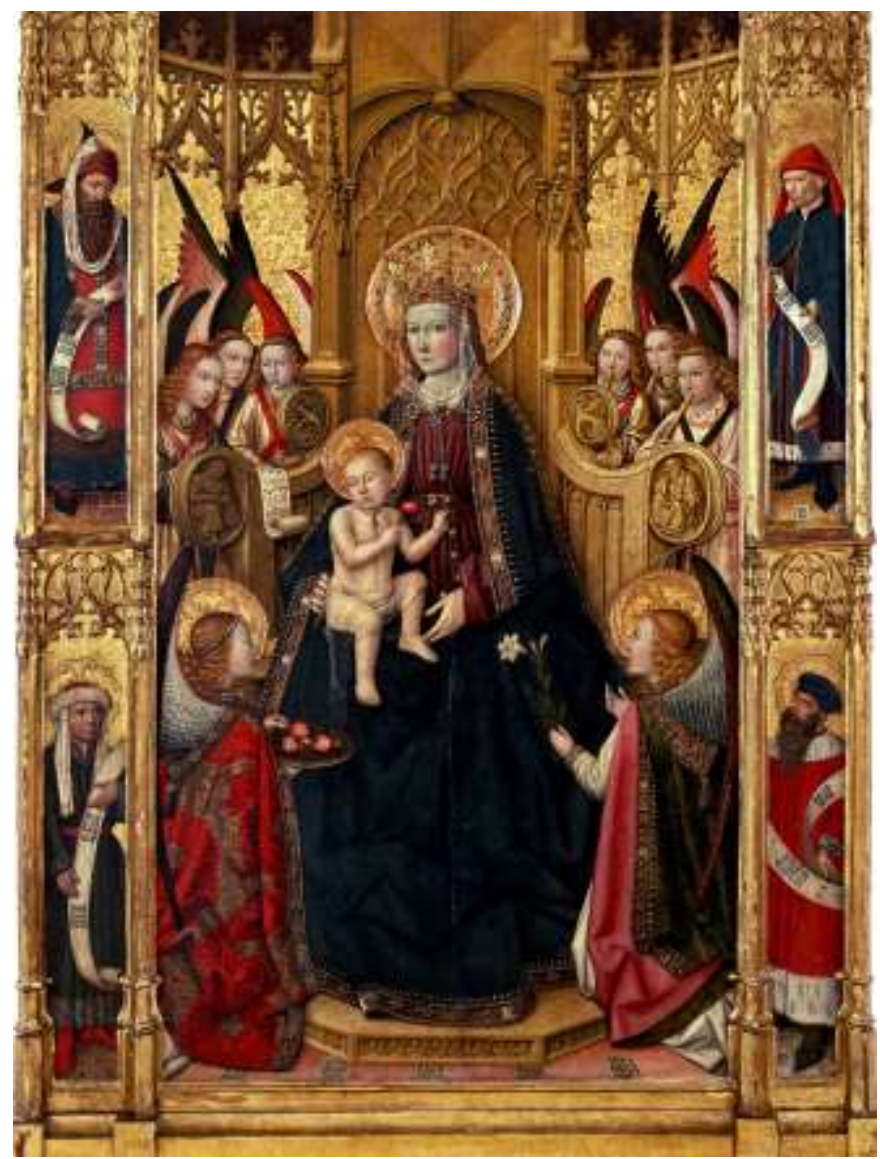

Fig. 4. JAUME Huguet, The Virgin and Child with angels (La Mare de Déu), Vallmoll Altarpiece, 1450. Museu Nacional d'Art de Catalunya, Barcelona. Image from Wikimedia Commons (Last access: 16/08/2014).

12 Fra ANGelico, Madonna and Child with four angels, central panel of the Perugia Altarpiece (Guidalotti Polyptych), 1447-1448, tempera and gold on wood, 128 x $88 \mathrm{~cm}$. Galleria Nazionale dell'Umbria, Perugia.

${ }^{13}$ The altarpiece was originally painted for the chapel of San Nicola in the church of San Domenico in Perugia. 
Jaume Huguet (1412-1492), in The Virgin and Child with angels of the Altarpiece of La Mare de Déu at Vallmoll, c. 1450 (Fig 4), ${ }^{14}$ represents Mary uplifted in splendid scenery as an imposing Queen of Heaven, while, with a luxurious crown of gold and jewelry, receives with her Child the homage of six musician angels and two offering angels. In the foreground, in effect, two kneeling angels offer to the Virgin a tray of red roses and a stem of lilies, respectively. The painter adds moreover a revealing detail: Jesus, whose chest exhibits a pendant of red coral (symbol of the blood of his future Passion), has picked up from the tray of the first angel a red rose -as accepting already in advance to shed his blood on Calvary - , which he presents with shyness to his Mother, to whom the second angel gives the stem of lilies, a conventional metaphor of her virginity and purity.

\subsection{From the Virgin of Humility to the human Mother}

In its primordial expression, the iconographic motif of The Virgin of Humility characterizes Mary sitting with modest aspect on the ground (sometimes with a cushion), carrying with tenderness the Child in her lap, instead of figuring her majestically crowned and seated on the heavenly throne. This theme is illustrated clearly in Stefan Lochner's Madonna of the Rose Bower. In this second iconographic typology we include also two works by Hans Memling and Sandro Botticelli, which, even presenting some strong compositional differences with the newly referred Marian subject, keep with it a certain emotional similarity as they reveal the human and natural facet -even domestic - of the supernatural Mother of God.

In the Madonna of the Rose Bower, c. $1440^{15}$ (Fig. 5), Stefan Lochner (c. 1400/10-1451) expresses in a very personal fashion the topic of the Virgin of Humility. ${ }^{16}$ Mary is shown here sitting on a parterre garden or a carpeting of strawberries and other tiny plants, while, squinting with modesty, holds on her lap her Child. Since a half-tondo on the cusp of the painting, in the center of the gold veil that two flying angels lift up, God the Father and the Holy Spirit in the form of a dove hover over the Mother of God. Lochner introduces here both divine Persons not only to affirm with forcefulness the dogma of the Trinity God the Son made flesh appears in the arms of his Mother-, but especially to confirm the mystery of the Mary's virginal divine motherhood, according to the archangel Gabriel's message at the Annunciation, when he communicated her

\footnotetext{
${ }^{14}$ JaUMe Huguet, The Virgin and Child with angels (La Mare de Déu), Vallmoll Altarpiece,, 1450 , tempera and gold on wood, $213 \times 160 \mathrm{~cm}$, from the parish church of Vallmoll (Alt Camp, Tarragona). Museu Nacional d'Art de Catalunya, Barcelona ( $\mathrm{N}^{\mathrm{o}}$ inv. 064066-000).

${ }^{15}$ StefAn LOCHNER, Madonna of the Rose Bower, c. 1440, oil on panel, 51 x $40 \mathrm{~cm}$. WallrafRichartz-Museum, Cologne.

${ }^{16}$ The Virgin of Humility was an iconographic theme that emerged in the mid-fourteenth century and became popular since the beginning of the fifteenth century.
} 
José María SAlvador GonZÁlez, Sicut lilium inter spinas. Floral metaphors in late medieval Marian iconography from patristic and theological sources

that "the Holy Spirit will come upon you, and the power of the Most High will overshadow you". ${ }^{17}$

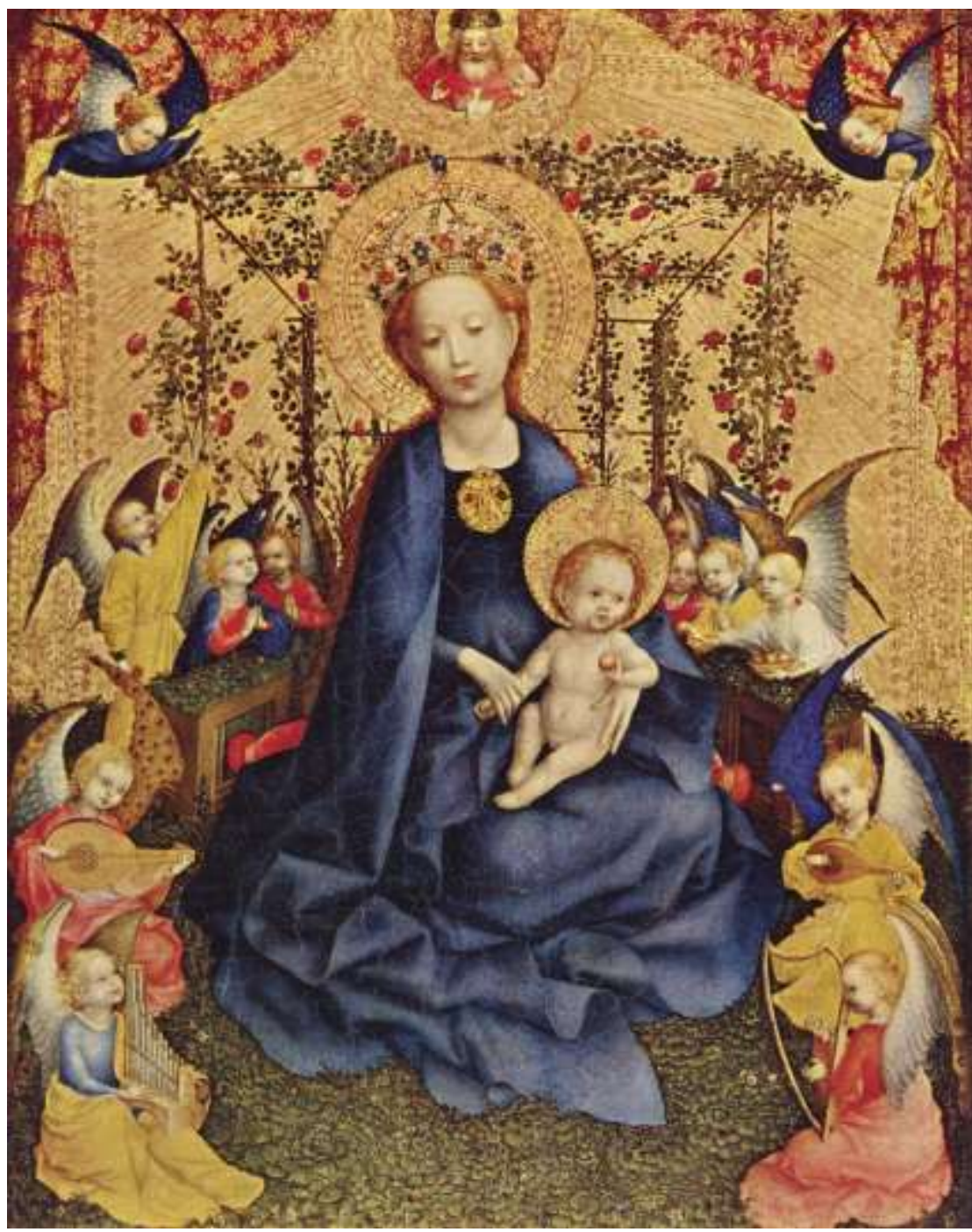

Fig. 5. STEFAN LOCHNER, Madonna of the Rose Bower, c. 1440. Wallraf-Richartz-Museum, Cologne. Image from Wikimedia Commons (Last access: 15/08/2014)

Some angels surround the Virgin and the Child in an attitude of tribute and submission: some of them toll musical instruments in the foreground; others, in the intermediate zones on the left, revere the holy couple or collect roses of the high branches for them; another angel, to the right of the scene, offer apples to them. To this purpose, the detail of the divine child, as the new Adam, catching already in this Rose Garden (heavenly Eden) one of the apples offered to him by this last angel (a good angel) is not insignificant: one can wonders if Jesus would want to prefigure with this action his assigned divine mission of reversing and correcting completely (redeeming) the ill-fated act of Adam and Eve in the

17 "Spiritus Sanctus superveniet in te et virtus Altissimi obumbrabit tibi." (Lk 1,35). In Biblia Sacra iuxta Vulgatam Clementinam. Nova editio, Madrid, La Editorial Católica, Col. Biblioteca de Autores Cristianos, 12a edición, 2005, p. 1011. 
Garden of Eden when they got the earthly apple offered by the devil (the bad or rebel angel)?

Otherwise it is necessary to highlight the series of floral components inserted in this panel of Stefan Lochner. The lilies and white roses allude conventionally to the Mary's purity and virginity. The red roses and strawberries, by its reddish color, are generally regarded as symbols of the Christ's Passion and of the suffering and bitterness that it induced in the Virgo Dolorosa's soul. On the other hand, the pergola of red and white roses that surrounds and protects the Virgin, together with the parterre garden on which she sits, illustrate with relevance the passage of the Song of Songs on the hortus conclusus, a metaphor that symbolizes the Mary's perpetual virginity. We will see later how these suitable interpretations expand and enhance in a superlative measure with the exegesis of the Church Fathers and theologians that we will discuss shortly after.

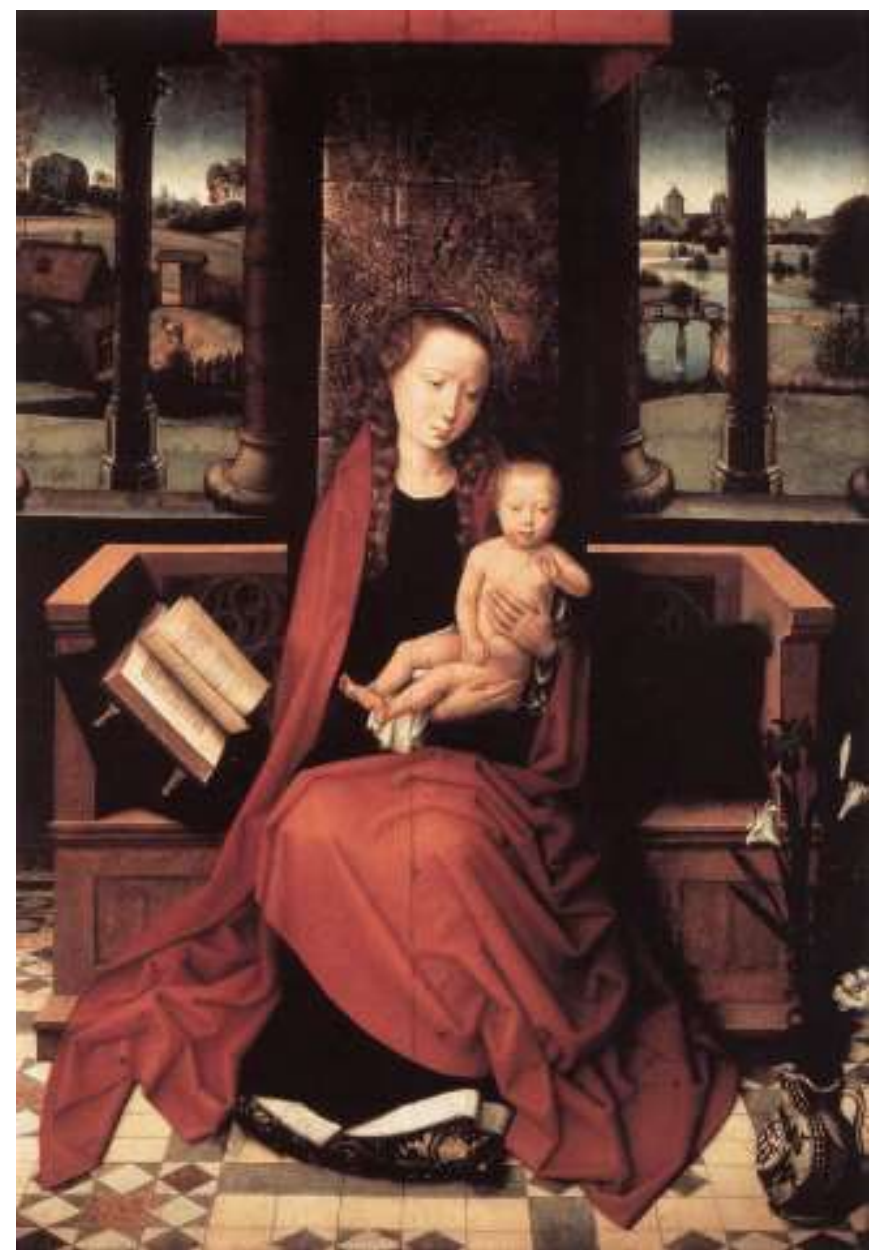

Fig. 6. HANS MEMLING, Virgin and Child, c. 1480s. Staatliche Museen, Berlín. Image from Wikimedia Commons (Last access: 14/08/2014)

Hans Memling (1430-1494), in his Virgin and Child at the State Museum of Berlin (Fig. 6), ${ }^{18}$ brings a human and quite domestic version of Mary. Far from

\footnotetext{
${ }^{18}$ Hans MemLing, Virgin and Child, c. 1480 s, oil on wood, 81 x $55 \mathrm{~cm}$. Staatliche Museen,
} Berlin. 
José María SALVAdOR GonZÁlez, Sicut lilium inter spinas. Floral metaphors in late medieval Marian iconography from patristic and theological sources

being enthroned with solemnity, girded with ostentatious crown of gold and gems, and receiving the grandiose tribute by a cortege of angels and saints, this Virgin of Memling, bareheaded and dressed with simple clothing, seems to reflect the friendly aspect of a normal middle-class mother: sitting with simplicity on a wooden bench next to a bow window of her home, she carries on her arms her naked baby, while interrupting the prayer she was reciting on the open book next to her. The white lilies and blue flowers - probably gladioli or, perhaps, aquiline (Aquilegia vulgaris) — that emerge from a porcelain vase in the lower right corner of the scene are interesting for our purposes here.

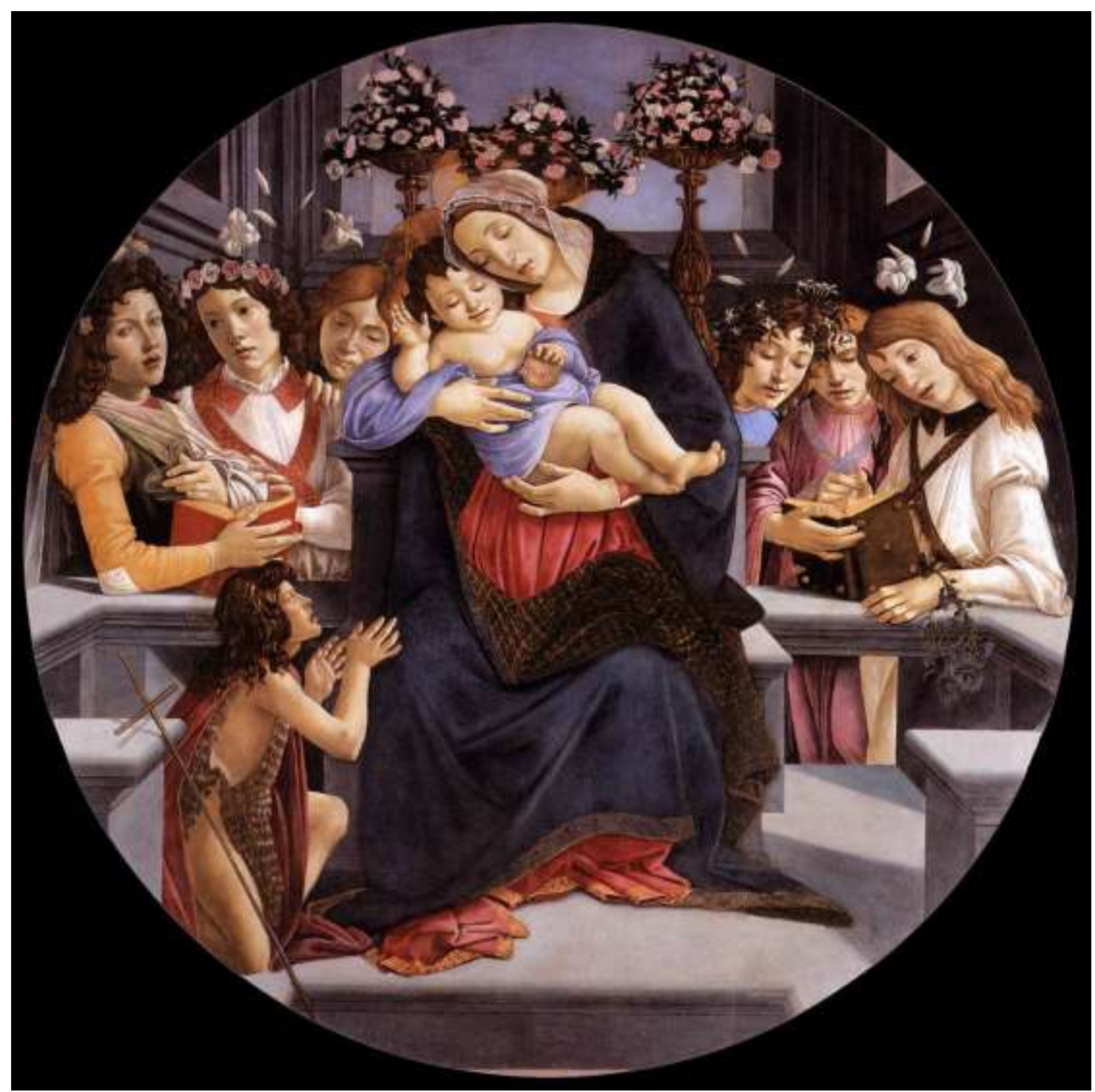

Fig. 7. SANDRO BotTICELLI, Virgin and Child with six angels and St. John Baptist, c. 1485.

Galleria Borghese, Rome. Image from Wikimedia Commons (Last access: 15/08/2014)

Sandro Botticelli, in his Virgin and Child with six angels and St. John Baptist, c. $1485^{19}$ (Fig. 7), brings an interpretation half-way between the

\footnotetext{
${ }^{19}$ SANDRo BotTiCELLI, Virgin and Child with six angels and St. John Baptist, c. 1485, tempera on wood, diameter $170 \mathrm{~cm}$. Galleria Borghese, Rome.
} 
supernatural Maiestas Mariae and the humanized mother of the fragile kid. The first situation is expressed by the angels who sing and regale to the Mother of the Redeemer, as well by her enthroned pose in the context of a solid palatial scenery. The situation of homely mother of a Jesus of human nature is reflected twice through the gestures of both: first of all, through the lovely motion of Mary's motherly tenderness, in almost wrapping his Only Begotten Son between her belly, her arms and her cheeks, as recalling the happy time when she gestated him in her uterus; secondly, through the gesture of Jesus, who, even half asleep seems to bless with his right hand his cousin John the Baptist, while holding in his left hand a cracked grenade, which reveals by the crack its red pimples, foreshadowing symbols of the drops of blood of his future Passion.

The many floral factors that Botticelli includes in this tondo are quite significant: in addition to the pink and white roses that, as a possible metaphor of the rosary, fulfill the three tall vases in the background of the scene and gird in bushy diadem the head of the second angel on the left, three stalks of enormous white lilies, offered by as many angels (the third from left, and the first two on the right), frame Mary as to focus on eloquent symbol her virginity, while the small white flowers -apparently, tuberoses (Polianthes tuberosa) interlaced in crown on the head of the first angel to the right would seem to refer to the lyrical compliment nardus mea dedit odorem suum, set forth by the Wife in the Song of Songs, ${ }^{20}$ while the surprising ring of purplish flowers that the last angel on the right-hand end of the scene exhibits in his wrist could perhaps foreshadow the crown of thorns of the Passion.

\subsection{The Sacra Conversazione}

This iconographic subject, that depicts the Virgin Mary -almost always enthroned - with her Child in her arms accompanied by several saints, with which she seem to be dialoguing, is exemplified here by two works by Rogier van der Weyden and Sandro Botticelli.

Rogier van der Weyden, in his Virgin of the Medici (Fig. 8), c. $1450,{ }^{21}$ structures the topic of the Sacra Conversazione by introducing as confidants of the Madonna and her Child the saints Peter and John the Baptist (patron saint of the city of Florence) and, to our right, the saints physicians Cosme and Damian, protectors of the Medici family, ${ }^{22}$ almost surely the orderer of this painting. Bareheaded, Mary stands here in her condition of Virgo Lactans, thus

\footnotetext{
${ }^{20}$ Songs 1,11 .

${ }^{21}$ RoGIER VAN DER WEYDEN, The Virgin of the Medici, c. 1450, oil on wood, 61,7 x 46,1 cm. Städelsches Kunstinstitut und Städtische Galerie, Francfurt am Main.

${ }^{22}$ It is easy to see why the medical saints Cosmas and Damian were the protectors of the Medici family, if one considers that the word "medical doctors" was translated into Italian medici, which is the surname of that very powerful Florentine family of bankers and politicians. Moreover, Cosme is precisely the name of the more representative and strong member in that family, Cosimo de' Medici the Old (Cosimo il Vecchio), who became, in effect the first Signore of the then Republic of Florence. I am grateful to Patricia Grau-Dieckmann for reminding me of the fact that saints Cosmas and Damian were medical doctors.
} 
accentuating the natural(istic) bias that the Flemish painters liked to bring to their sacral themes. The floral ingredients included in the work, besides the synthetic fleur de lis of the coat of arms (symbol of Florence) in the stone base of the scene, are very significant. The lilies and violet gladioli emerging from the vase in the center of the basement highlight in the foreground by their Mariological symbolism. The other plants and flowers -among which one can likely discern violets, common daisy (bellis perennis) and strawberries - that fill the parterre on which the characters and the canopied throne of the Queen of Heaven rest are also interesting. It becomes apparent that this flowery parterre displays the biblical quote of the hortus conclusus as an analogy of the Mary's perpetual viginity.

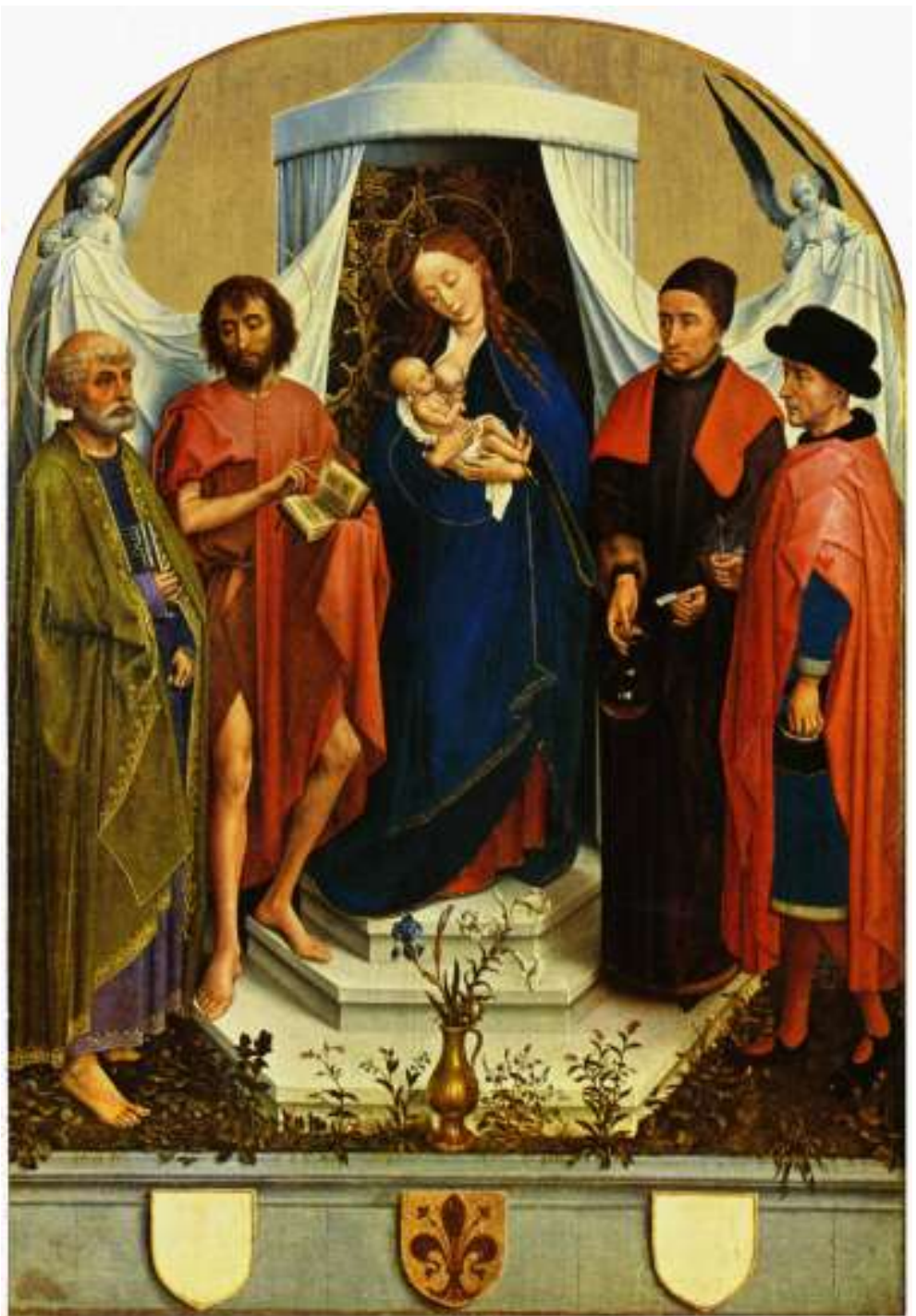

Fig. 8. ROGIER VAN DER WEYDEN, The Virgin of the Medici, c. 1450. Städelsches Kunstinstitut, Francfurt am Main. Image from Wikimedia Commons (Last access: 15/08/2014)

In his Virgin enthroned between saints John the Baptist and John the Evangelist (Bardi Altarpiece), 1484 (Fig. 9), Sandro Botticelli raises a warm version, with dense symbolic core, of Sacra Conversazione, in which Mary outlines the gesture of opening her chest to breast-feed her child, in a subtle form 
José María SALVAdOR GonZÁlez, Sicut lilium inter spinas. Floral metaphors in late medieval Marian iconography from patristic and theological sources

of Virgo Lactans. ${ }^{23}$ The florentine Giovanni de' Bardi, principal of this painting, chose as partners for the Virgin his two patron saints: Saint John the Baptist (also the patron of Florence, as already said) -with the bowl for baptizing at his feet and with his cruciform signet waving a phylactery inscribed with the motto Ecce Agnus Dei qui tollit pechata (sic) $m[$ undi] —, and Saint John the Evangelist, as the elder visionary in Patmos, with his pen, his book and the tetramorphic eagle located on the ground behind him.

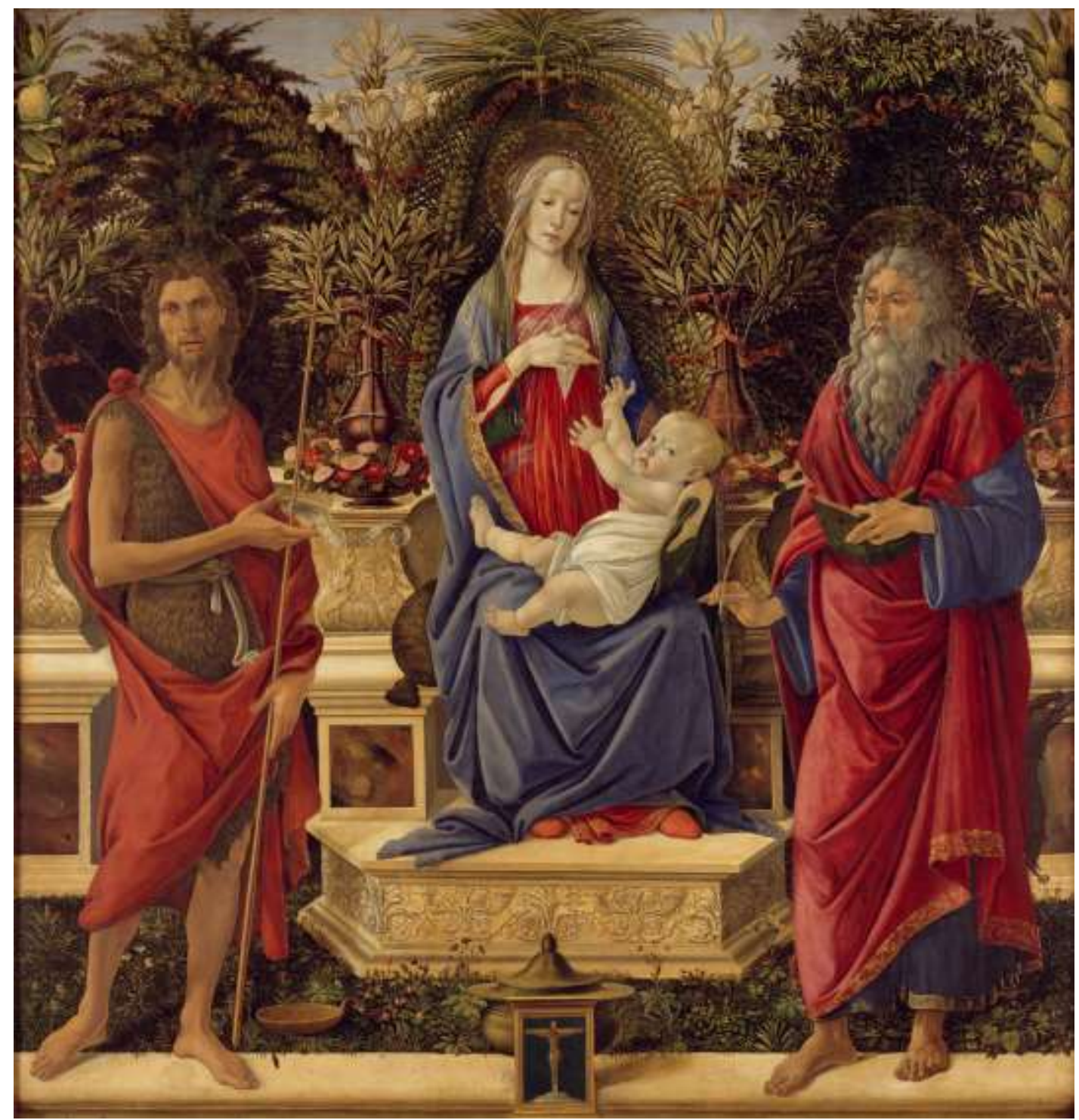

Fig. 9. SANDRO BOTTICELLI, Virgin enthroned between saints John the Baptist and John the Evangelist (Bardi Altarpiece), 1484. Staatliche Museen, Berlin. Image from Wikimedia Commons (Last access: 15/08/2014)

For our interests the complex and sophisticated plexus of Marian symbols underlying in the multiple plant features is the more valuable element in this Sacra Conversazione, symbols inspired by the Song of Songs and by

${ }^{23}$ SANDRO BotTICELLI, Virgin enthroned between saints John the Baptist and John the Evangelist (Bardi Altarpiece),1484, tempera on wood, 185 x $180 \mathrm{~cm}$. Gemäldegalerie, Staatliche Museen, Berlin. 
the Book of Ecclesiasticus (Wisdom of Sirach). The Virgin is enthroned on a garden of varied little flowers and framed/protected by a pergola or a very elaborated plant trellis. Both factors, garden and closing pergola, symbolize the Mary's perpetual virginity, in accordance with the metaphor of the hortus conclusus from the Song of Songs. The two enormous stems of lilies that frame symmetrically the vegetable niche where the Virgin manifests herself transmit this same idea.

The metaphors hidden under the many plants and flowers that make up the vegetable scenery of this panel of Botticelli are much finer and original. Such metaphorical figures are inspired by the following excerpt from the Ecclesiasticus in praise of wisdom: ${ }^{24}$

Quasi cedrus exaltata sum in Libano,
Et quasi cypressus in monte Sion;
Quasi palma exaltata sum in Cades,
Et quasi plantatio rosae in Iericho.
Quasi oliva speciosa in campis,
Et quasi platanus exaltata sum iuxta aquam in plateis. ${ }^{25}$

I am exalted as the cedar in Libanus

And as the cypress tree on Mount Sion;

I am exalted as a palm in Cades

And as a haven for roses in Jericho.

I am exalted as a fair olive tree in a pleasant field,

And I am exalted as a plane tree next to the water in the squares.

When analyzing, in effect, the components of this scenery, all botanical specimens referred to in this passage of the Ecclesiasticus are seen here, to which the inscriptions in the banners or phylacteries rolled in them refer accurately. Thus, in both upper corners there are two branches of lemon tree with two lemons, each one of them showing their corresponding scroll with the legend (barely legible) Quasi cedrus exaltata sum in Libano. ${ }^{26}$ The plant niche that frames John the Baptist is made up of a network of branches of cypress, in whose top part is unfolded a banner with the phrase Quasi cypressus in monte Sion. ${ }^{27}$ The niche that shelter the Virgin is composed of an elaborated interlace of palmleaf -similar to those usually made for the Palm Sunday procession-, in whose

${ }^{24}$ Although in the Jewish Bible those verses of the Ecclesiasticus were originally written to praise the wisdom, the Christian exegesis soon derived them toward a Mariological meaning, applying them entirely as praise to the Virgin Mary.

${ }^{25}$ Ecclesiasticus, 24, 17-19. In Biblia Sacra iuxta Vulgatam Clementinam, op. cit., pp. 654-655.

${ }^{26}$ Ecclesiasticus, 24, 17. Op. cit., p. 654. It is important to emphasize the semantic displacement produced by an erroneous reading of the biblical text by the iconographic programmer of the Bardi Altarpiece: he read citrus (lemon) instead of Cedrus (cedar), due to the spelling and phonetic similarity of both Latin words.

${ }^{27}$ Ecclesiasticus, 24, 17. Op. cit., p. 654. 
cusp, expanding around the cross, a scroll exhibits the verse Quasi palma exaltata sum in Cades. ${ }^{28}$ In the four large vases (with aspect of fruit bowl) filled with white and red roses located on the quadruple marble bank behind the throne and in the intermediate zone of the left and right edges one can read in the respective girdles the wording Quasi plantatio rosae in Iericho. ${ }^{29}$

Behind these four fruit bowls there are other large vases, from which leafy olive branches filled with black olives emerge, in each one of the four bands you can read Quasi oliva speciosa in campis. ${ }^{30}$ Finally, at the top of the vegetable niche that frames John the Evangelist, the meandering strip allows you to see the phrase Quasi platanus exaltata sum iuxta aquam in plateis, ${ }^{31}$ between the whimsical branches and leaves that interweave it. ${ }^{32}$ All these elements confirm that Botticelli managed to visualize with effectiveness the precise doctrinal patterns that the iconographic programmer of this splendid altarpiece dictated to him to make this a radiant poetic exaltation of the unmatched glory and the sublime virtues of Mary.

\subsection{The Coronation of the Virgin}

This Marian subject is very well typified by the altarpiece of Fra Filippo Lippi in the Galleria degli Uffizi in Florence. In this overflowing scene (Fig 10) ${ }^{33}$ originally painted as the altarpiece for the high altar of the church of Saint Ambrose, in the homonym convent of Benedictine nuns in Florence-, Fra Filippo Lippi (1406-1469) proposes an exuberant and unusual interpretation of the already then consolidated theme of the Virgin Mary's Coronation. The painter places here Christ standing before the throne in the action of crowning his kneeling mother, while such colorful ceremony is attended by a pleiad of angels and many saints, among which St. Ambrose, the convent's patron saint, and St. John the Baptist, the patron saint of Florence, stand out in the foreground at both borders of the painting.

\footnotetext{
${ }^{28}$ Ecclesiasticus, 24, 18. Op. cit., p. 654.

${ }^{29}$ Ibidem.

${ }^{30}$ Ecclesiasticus, 24, 19. Op.cit., p. 655.

${ }^{31}$ Ibidem.

32 The indefinite ambiguity with which Botticelli painted the sheets of this "plane tree" seems to suggest that neither the artist nor the iconographic programmer of the painting knew the morphology of the trunk, branches and leaves of the plane tree alluded in the Ecclesiasticus. The Latin term platanus is translated in Spanish simply as "plátano", which could refer both to the ornamental plane tree of the Platanaceae family, as to the tropical bananas of the family of the Musaceae, whose fruits (bananas) are eatable. It is evident that the leaves painted by Botticelli in this sector of the altarpiece do not correspond to any of the platanus species of the two mentioned families. Apparently, lack of accurate information on this elusive specimen tree, the painter has allowed here for him a clear "poetic license".

${ }^{33}$ FRA FILIPPO LIPPI, The Coronation of the Virgin, c. 1439-1447, tempera on wood, $200 \times 287$ $\mathrm{cm}$. Galleria degli Uffizi, Florence.
} 

medieval Marian iconography from patristic and theological sources

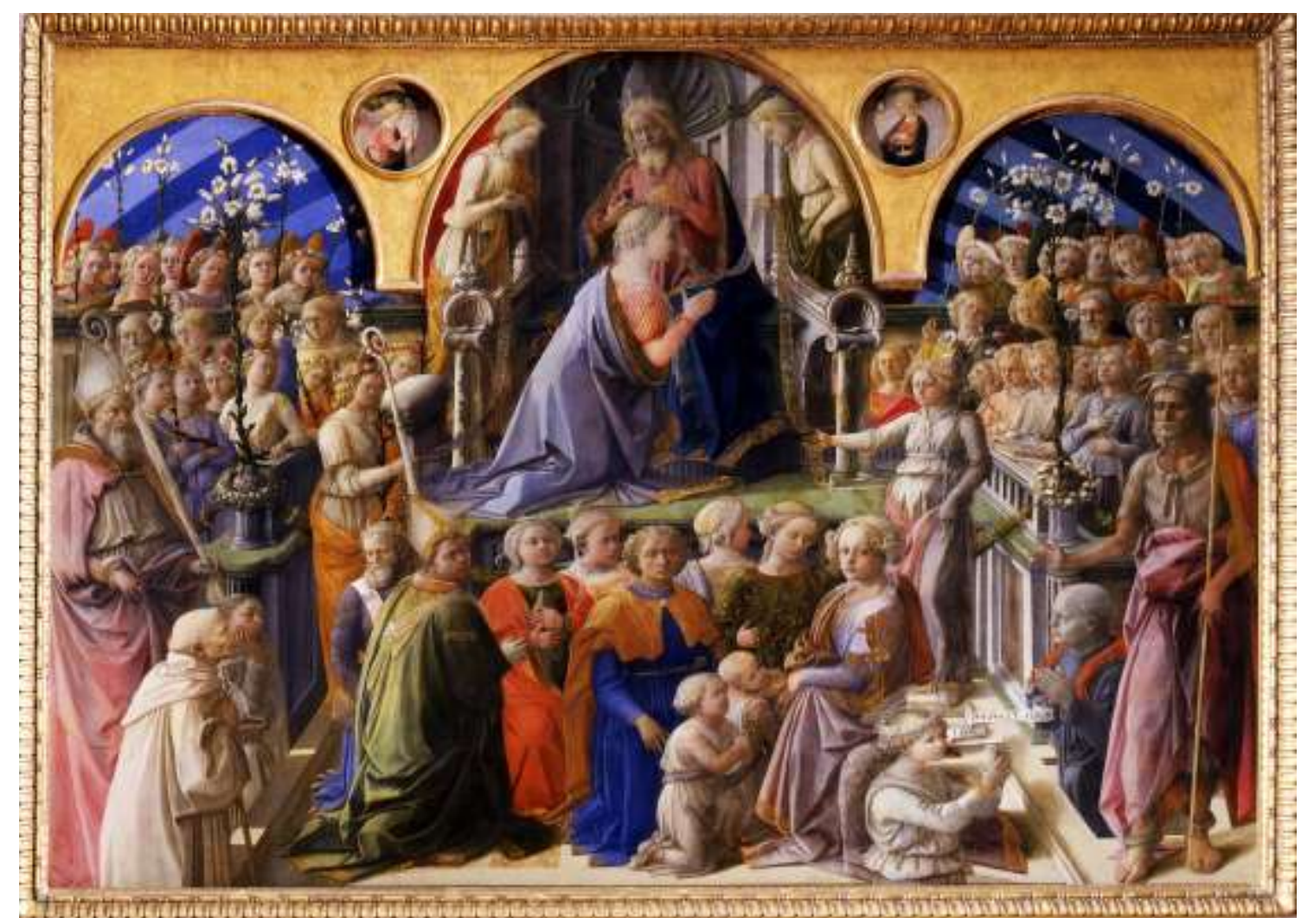

Fig. 10. FRA FILIPPO LIPPI, The Coronation of the Virgin, c. 1439-1447. Galleria degli Uffizi, Florence. Image from Wikimewdia Commons (Last access: 14/08/2014)

The huge stalks of white lilies symmetrically distributed on the scene are very valuable for our aims: the two largest of them sprout as if by magic from two architectural ornaments at the intermediate level, ornaments that, respectively surrounded by a garland of small flowers (daisies and tuberoses?) and by a wreath of roses, serve as an anchor to four festoons, which disappear after the saints and angels; the other stems of lilies are brought as an offering by the court of honor's numerous angels, whose heads exhibit wreaths of white or red roses and other small flowers. In view of this complex and repeated floral decoration of lilies, roses, lilies and daisies, it seems certain that Fra Filippo Lippi assumes the conventional interpretation, in the sense of presenting these flowers as symbols of the Mary's purity, charity and virginity. We shall see later that this partially valid-conventional interpretation should be complemented and enriched with other doctrinal meanings emerging from the medieval theological tradition.

\section{A hermeneutic approach in patristic and theological key}

Not a few Church Fathers and medieval theologians, in order to highlight the unique spiritual gifts and the exalted virtues of Mary, qualify her with some bucolic floral metaphors, naming her, for example, "lily", "madonna lily", "rose", "tuberose", "violet" or some other beautiful and fragrant flower. Therefore, they do not hesitate to take inspiration from some quotations from the Old Testament alluding to beautiful flowers, pleasant fragrances and even 
precious stems and trees, which serve them as suggestive prefigurations of the Virgin in her radiant fullness of grace and virtues.

Already in the mid-fifth century an anonymous writer, when paraphrasing several quotes from the Old Testament, praises Mary for her virginal divine motherhood, comparing her with flowers, plants and fragancies in these poetic terms:

You, O Virgin, did grow up as a cedar incense; because you gave smell as the Lord's paradise. As a palm you are exalted in the glory; because the world is filled with your sweetness. You, as a noble olive tree, brought the fruit of the glory, and your flower gave soft smell. You, as the vine, sprout a bunch, and the joy of your wine is drunk without exhausting it. As the incense you did receive incense, and as a select myrrh, you were offered gold and myrrh. As the terebinth tree you stretched out your branches, under whose shade the wandering peoples came running. As the plane tree you are exalted above the waters; since you gestated in your womb the source of life. ${ }^{34}$

Later the same author goes on by comparing Mary with a flower of soft smell and with a vine that produced a bunch for the faithful drink of its wine ${ }^{35}$ Further explaining this phytomorphic analogy, equates her to a rose of beautiful colors sprung among women, before identifying her to a chaste lily that issued its fragrance, as she was chosen for gestating in her belly the everlasting God, a childbirth that remains for eternity. ${ }^{36}$ At the end, for this author the botanical equivalencies aforementioned by him mean the Virgin's chastity or purity and, in particular, her supernatural privilege of being the virginal mother of the Redeemer made man.

Some decades later the Syrian hymnographer St. Romanus the Melodist (c. 485-555/62) argues that the Holy Scriptures, after identifying Jesus as the vase of the manna and as the flower sprung from the root of Jesse, calls the Virgin whith the metaphors of

\footnotetext{
34 "Tu coaluisti, Virgo, sicut cedrus in incenso; nam sicut paradisus Domini dedisti odorem. Tu sicut palma exaltata es in gloria; nam dulcedine tua mundus impletur. Tu sicut oliva nobilis fructum provexisti gloriae, et flos tuus odorem suavitatis. Tu sicut vitis protulisti racemum, et laetitia vini tui bibitur et non deficit. Tu sicut incensum incensum accepisti, et sicut myrrhae electae aurum et myrrha tibi prolata sunt. Tu sicut terebinthus extendisti ramos, cuius sub umbram gentes errantes accurrerunt. Tu sicut platanus exaltata es super aquas; nam fontem vitae in utero portasti." (ANONIMOUS WRITER (mid-fifth century), In Nativitatem Domini. In Sergio Álvarez CAMPos, Corpus Marianum Patristicum, Burgos, Aldecoa, 1976, vol. IV/1, p. 515).

35 "Tu sicut oliva nobilis fructum provexisti gloriae, et flos tuus odorem suavitatis. Tu sicut vitis protulisti racemum, et laetitia vini tui bibitur et non deficit." (Ibidem).

36 "Tu sicut rosa formosi coloris inter mulieres germinasti, et sicut lilium castum fragrantiam emisisti. Tu illum ante saecula Deum ut portares electa es, et usque in saecula manet partus tuus." (Ibidem).
} 
José María SALVAdor GonZÁLEZ, Sicut lilium inter spinas. Floral metaphors in late medieval Marian iconography from patristic and theological sources

flower, stem, ark, the same who gestates in her womb, opened by the Holy Spirit, and that afterwards remains closed for ever, so that everyone may say: she gave birth being Virgin, and after childbirth remains virgin again. ${ }^{37}$

With such botanical comparisons the Melodist refers poetically to the divine motherhood of Mary and her perpetual virginity, before, during and after the act of giving birth to Jesus.

In the second half of the sixth century the elegant Italian-Latin hymnographer St. Venantius Fortunatus (c. 530-C. 600), bishop of Poitiers, expresses a hymn to the Mary's virginity:

Therefore, the pious Virgin Mary, Mother of God, shines,

And leads the sheep from the flock of the virginal Lamb.

She herself, surrounded by the assembly of the maidens,

Attracts by the light of her purity to splendid camps

Through heavenly delicacies that sing their promises,

She picks up violet and grab those roses.

They break with the thumb the precious stones of the parents and the lilies

And harvest with exuberant flowers what it is worshipped. ${ }^{38}$

And in another poem in praise of the Virgin, Venantius Fortunatus expresses:

Blessed be Mary forever, honored be her name;

Do we in her praise the work of the noble art of the maker.

$[\ldots]$

Therefore, surpassing the roses in ruddiness, and the lilies in candor, she is the new flower of the earth $[\ldots] .{ }^{39}$

\footnotetext{
37 “Te, Iesu, monstrat Scripturas: alia manna et vas indicat, alia vero ex radice florem nuntiat. Et matrem tuam vocant florem, virgam, arcam, eam quae sinu portat per Spiritum aperta et post haec manet clausa; ut quisquis dicat: Virgo parit, et post partum iterum manet virgo." (ST. Romanos the Melodist (Romanus Cantor), Hymnus 12, 6. In Alvarez Campos 1979, vol. IV/2:129-130).

38 "Inde Dei Genetrix pia Virgo Maria coruscat, virgineoque Agni de grege ducit oves.

Ipsa puellari medio circumdata coetu luce pudicitiae splendida castra trahit.

Per paradisiacas epulas sua vota canentes

ista legit violas, carpit et illas rosas.

Patrorum gemmas ac lilia pollice rumpunt,

et quod adoratum est flore comante metunt." (St. VenANTIUS ForTUNATUS, Miscel. 8, 3, 2532. In nomine Domini nostri Iesu Christi et Domnae Mariae Matris eius de virginitate. PL 88, 266 B-267 A. In Álvarez CAMPos 1981, vol. VI: 375).

39 "Nomen honoratum, benedicta Maria per aevum; ad laudem artificis nobilis artis opus.

[...] Inde rubore rosas, candore hinc lilia vicens:
} 

medieval Marian iconography from patristic and theological sources

Another anonymous author of the sixth century says in lyrical terms the miraculous conceptio of the Savior in the Virgin Mary's womb, auguring rhetorically that "faith expands the beautiful tents of the resplendent uterus", that the virtue of the Most High covers her with his shadow, "that the Holy Spirit resonates with slight whisper and the soft aura revives the Virgin after rejecting the natural heat", and that "the virginal womb will be crowned with the garlands of modesty." 40 The effusive writer goes on looking forward to, when Mary conceived Jesus virginally,

the rose's bright radiance exhale its aroma, the white lily exhibit its wit, the soft violet glitter, the purple morning glory (ipomoea purpurea) fill with flowers, and the beautiful thalamus of Christ embellish with diverse splendor. ${ }^{41}$

It is thus clear that for this unknown writer "the rose", "the lily", "the violet" and the various species of "purple morning glory" are many other idyllic analogies to designate the Mary's virginal divine motherhood.

Almost two centuries later the influent Syrian theologian St. John Damascene (675-749), in a first sermon on the Virgin's birth, had exalted her with the exclamations "Oh, beautiful and sweetest maiden! Oh, lily among thorns, born from the very generous and maximally royal root of David!", ${ }^{42}$ and "Oh rose, that have been born in among thorns, i.e. from among the Jews, and inundated everything with a divine smell!" 43 In a second sermon on the same subject he continues his praises in phitomorphic terms, calling Mary as "unfading rose, infinitely fragrant, with whose perfume the Lord rested with delight in you, and from which he, flourishing, repressed the mundane smell". ${ }^{44} \mathrm{He}$ then further expands his botanic figurations in calling Mary "lily, whose son Jesus wears these clothes of the lilies of the field, exhaling the sweet scent of the roses of the

flos novus ex terra, quod polus arce colat." (St. VENANTIUS FortunAtUS, Caput VII. In laudem sanctae Mariae Virginis et matris Domini. PL 88, 281).

40 "Expandat nunc fides splendentis uteri pulchra tentoria, obumbret virtus, Spiritus sibilet, naturali calore depulso tenuis virginem aura refoveat, et fluente refrigerio spiramentis coelestibus ventiletur, alvus virginalis sertis verecundiae coronetur." (ANONIMOUS WRITER (sixth century), Sermo Maurinus Ps. Agustini 120. In Álvarez CAMPos 1981, vol. VI: 252).

41 "Flammeus ibi rosae fulgor anhelet, albens lilium candicet, mollis viola rutilet, purpurei spargantur flores, et vario nitore depictus Christi thalamus exornetur." (Ibidem).

42 "O speciosissima dulcissimaque puella! o lilium inter spinas, ex generosissima et maxime regia radice Davidica progenitum! Per te regnum sacerdotio locupletatum est." (ST. JOHN DAMASCENE, In Nativitatem B.V. Mariae, 6. PG 96, 670).

43 “O rosa, quae ex spinis, Judaeis scilicet, orta es divinoque odore cuncta perfudisti!” (Ibidem).

44 "Ave, rosa immarcessibilis, infinite fragrans; cujus odore Dominus oblectatus, in te requievit, et ex qua florescens ipse, mundi odorem repressit. Ave, pomum bene olens, fructus sterile prognatus [...] cujus Christus puritatem decerpens, intemeratum mundo odoris suavitatem in epulis habuit." (ST. JoHN DAMASCENE, Homilia II In Nativitatem B.V. Mariae, 7. PG 96, 691). 
José María SAlvador GonZÁlez, Sicut lilium inter spinas. Floral metaphors in late medieval Marian iconography from patristic and theological sources

Holy Spirit.",45

And in another paragraph of that same second homily, the Damascene exalts the Virgin for her egregious virtues, dubbing her "flower, [...] from which another flower similar to the [first] flower arises, in exact reference to his mother", before figuring her with the bucolic appeal of "distilling tuberose, that difuses the aromas of chastity as if they were ointments, whose emanation is the smell of the most soft being, about whom the Song of Songs says: Nardus mea dedit odorem suum."

To greater abundance, in another homily on the Annunciation, the Damascene greets Mary as "full of grace", "because you surpass the lilies in fragrance, and the roses in ruddiness, and because you flourished surpassing the spring in a variety of splendors." of the Virgin Mary, when referring to the transfer of her soul to heaven by means of angels and archangels, the holy monk of Damascus states that in the transit of Mary to heaven "the air is blessed, the ether sanctified", because she is "the flower of the fields", 48 and is manifested "As a lily in the midst of the thorns", by which the maidens love here, and run "to the flavor of your perfumes." 49

It is clear, therefore, that for the fervent Mariologist of Damascus the rhetorical figures of "flower", "lily", "rose", "exuding tuberose", "lily among thorns", "unfading rose" and other similar expressions are obvious rhetorical similes of the Virgin's eminent virtues, particularly, her chastity, the fullness of her grace and virtues, her divine motherhood and her virginal conception of God the Son made man.

45 "Ave, lilium, cujus proles Jesus haec agri lilia vestit; suave spirans Spiritus rosarium, ex qua Christus stola minime neta, cujus decore Salomonis ornatus omnis obscuratur, absque semente indutus est." (Ibidem).

46 "Ave, flos, [...] ex qua flos flore similis, matrem exacte referens consurgit (...). Ave, nardus fluens, unguentariorum more castitatis aromata irrigans, quorum evaporatio suavissimi illi odor est, qui in Canticis dicit: Nardus mea dedit odorem suum. [...] Ave, cinnamomum, spiritalis paradisi aroma integritatis, cujus odor ei dulcis est". (Ibidem).

47 "Ave, gratia plena, quoniam super lilia fragrans fuisti, et super rosas rubicunda, ac super varie decorum ver effloruisti." (ST. John Damascene, Homilia in Annuntiationem B.V. Mariae. PG 96: $655)$.

${ }^{48}$ Frente a la tradicional identificación de Jesús como "la flor del campo y el lirio de los valles", algunos teólogos medievales no dudan - como lo hace aquí San Juan Damasceno- en aplicar esas dos metáforas bíblicas a la propia Virgen María. Confronting the traditional identification of Jesus as "the flower of the field and the lily of the valleys", some medieval theologians do not hesitate -as it does here St. John Damascene - to apply these two biblical metaphors to the Virgin Mary herself.

49 "Te cum angelis archangeli transvexerunt [...] Tuo transitu aer benedicitur, aetheri sanctitas conciliatur. Animam tuam coelum gaudens excipit (...) Quam pulcra, quam suavis facta es! tu flos campi, uti lilium in medio spinarum: propterea, adulescentulae dilexerunt te: in odorem unguentorum tuorum cucurrerunt." (St. JoHn Damascene, Homilia I in Dormitionem B.V. Mariae, 11. PG 96, 715-718). 

medieval Marian iconography from patristic and theological sources

Almost half a century later the french Benedictine Ambroise Autpert (c. 730784), ${ }^{50}$ in a famous text on the assumption attributed to him, ${ }^{51}$ compares the Virgin to a true garden of delights, where flowers of all kinds sprout and disseminate the perfumes of all the virtues, a garden tightly closed, in which the devil could not enter even with his insidious traps. ${ }^{52}$ With similar words, the author refers to the Mary's spiritual privileges, to her absolute fullness of grace, to her purity and perpetual virginity, to her total immunity from sin.

And, while St. Fulbert, bishop of Chartres (c. 960-1028), defines again Mary with the biblical figure "beautiful as a lily in the midst of thorns", 53 the Benedictine cardinal St. Peter Damian (c. 1007-1072) establishes a suggestive dialectical relationship, by applying this lily's metaphor to the Virgin and Christ himself, in function of some suitable quotations of the Old Testament. First of all, in effect, the holy monk says that Christ "is the singular flower of the holy Church", according to "what it is said [about him] in the Song of Songs: "I am the flower of the field, and the lily of the valleys", specifying that "This lily is not born in the mountains, but in the valleys, since God, that resists the proud, is present in the heart of the humble [Mary]. ${ }^{54}$ Shortly after Peter Damian sets the dialectical parallelism between the Virgin and her divine Son, by confirming that, if "Christ is called lily, also the mother of Christ is called lily, in accordance with what is added at the same Song of Songs: "As a lily among thorns, so is my friend between girls". ${ }^{55}$ As shown, this Benedictine saint sees these phitomorphic allusions ("lily of the valleys", "lily among thorns") as metaphors for the Virgin's humility and chastity.

\footnotetext{
${ }^{50}$ Ambroise Autpert was abbot of the abbey of San Vincenzo in the Volturno, in the Benevento Duchy.

${ }^{51}$ Ambroise AutPert (attributed), Epistola IX Ad Paulam et Eustochium De Assumptione beatae Mariae Virginis (epistle falsely attributed to ST. JEROME, under whose authorship is included in Migne). PL 30, 122-144.

52 "Unde canitur in eisdem Canticis de ea: Hortus conclusus, fons signatus, emisiones tuae paradisus (Cant. IV, 12). Vere hortus deliciarum, in quo consita sunt universa florum genera et odoramenta virtutum: sicque conclusus, ut nesciat violari neque corrumpi ullis insidiarum fraudibus." (AMBROISE AUTPERT (attributed), Epistola IX Ad Paulam et Eustochium De Assumptione beatae Mariae Virginis. PL 30, 132).
}

53 "Non tamen haec idcirco dixerimus, quod Dominus qui peccatores vocare venit, dedignatus sit matrem suam peccatores habere cognatos, inter quos speciosa velut inter spinas lilium apparet." (ST. Fulbert OF ChARTRES (FulBertus CARNOTENSIS EPISCOPUS), Sermo IV. De Nativitate Beatissimae Mariae Virginis. PL 141, 321).

54 "Singularis namque flos sanctae Ecclesiae ipse est, sicut de semetipso in Canticis canticorum loquitur, dicens: "Ego flos campi, et lilium convallium (Cant. II). " Hoc lilium non in montibus, sed in convallibus nascitur, quia superbis Deus resistens, in humilium cordibus invenitur." (St. Peter Damian, Sermo XLVI, III. In Nativitate Beatissimae Virginis Mariae (VIII Sept.). PL 144, 754).

55 "Lilium vocatur Christus, lilium dicitur et mater Christi, sicut in eodem Cantico subinfertur: «Sicut lilium inter spinas, sic amica mea inter filias » (Ibid.)." (Ibidem). 

medieval Marian iconography from patristic and theological sources

Some decades later, the Benedictine Church Doctor St. Anselm of Aosta (1033-1109), ${ }^{56}$ archbishop of Canterbury, ${ }^{57}$ inspired on the already mentioned passage of the Ecclesiasticus and in other biblical quotations, defines Mary as "stem of the Jesse's root", "cedar of Lebanon", "purple rose in Jericho", "cypress tree on Mount Zion". ${ }^{58}$ And in another sentence on the Assumption, St. Anselm insists in praising the Virgin because, for having giving birth to Christ, the Sun of justice, she has been 'hailed as a cedar in Lebanon, as a cypress tree on Mount Zion, and as select myrrh that gives a soft smell." $" 59$

Through these vivid botanical analogies St. Anselm seeks to illustrate the divine motherhood and the perpetual virginity of Mary: therefore he extolls her as the only parturient in which there is a fruitful virginity, which gave birth to the Son of God in her immaculate womb, retaining, however, the integrity of her chastity and without concupiscence violating the seal of her virginity. ${ }^{6}$

Half a century later the influential Cistercian master St. Bernard of Clairvaux ${ }^{61}$ (1090-1153), based on the presupposition that Jesus Christ, the flower sprung from the stem of the root of Jesse, loves the homeland of the flowers, concludes that, being he "the flower of the field and the lily of the valleys", is pleased to "feed between the lilies". ${ }^{62}$ Expanding soon after that poetic similarity between flowers and virtues, he argues that Jesus perfectly feeded in Mary, because "he found in her a great abundance of white lilies", as "the decorum of

\footnotetext{
${ }^{56}$ For a study of the doctrinal thought of this prestigious ecclesiastical author, see Obras completas de San Anselmo (Introducción general y versión castellana por Julián Alameda), Madrid, La Editorial Católica, Col. Biblioteca de Autores Cristianos, 1952-1953, 2 vols.

${ }^{57}$ Benedictine monk who was born in Aosta (northern Italy), St. Anselm was Archbishop of Canterbury (1093-1109): that is why he is known interchangeably as St. Anselm of Aosta or of Canterbury. In 1720 he was proclaimed a Doctor of the Church.
}

58 "O beata Dei genitrix, virgo Maria, templum Dei vivi, aula Regis aeterni, sacrarium Spiritus sancti. Tu virga de radice Jesse, tu cedrus de Libano, tu rosa purpurea in Jericho, tu cypressus in monte Sion; quae singulari privilegio sicut nescis in omnibus comparationem, ita nihilominus et angelicam superas dignitatem, cui novo et inaudito miraculo datum est ut Verbum quod ante saecula Deus genuit, fieret filius tuus, Deus et homo. Tu eum in fine saeculi genuisti, ut verus atque perfectus esset Dei Filius gemina quidem natura, sed una persona, Deus et homo, unus Emmanuel." (ST. ANSELM, Oratio LV, Ad eamdem sanctam Virginem Mariam. PL 158, 961).

59 "Felix namque es sacra virgo Maria, et omni laude dignissima, quia ex te ortus est sol justitiae Christus Deus noster. Sicut cedrus exaltata in Libano, et sicut cypressus in monte Sion, quasi myrrha electa dans suavitatem odoris (Eccli. xxiv, 17, 20). (ST. ANSELM, Oratio LX, Ad sanctam Virginem Mariam In Assumptione eius. PL 158, 965).

60 "O gloriosa puerpera, in qua sola reperitur fecunda virginitas, quae sic intemeratis visceribus Filium Dei protulisti ut illibatae pudicitiae cresceret integritas, non libido virginalis integritatis sigillum violaret." (Ibidem).

${ }^{61}$ Reformer of the monastic life, the main promoter of the Cistercian order and abbot of Clairvaux, St. Bernard was exalted to the rank of Doctor of the Church. It is designated with the nickname "Doctor Mellifluus" (Doctor Mellifluus).

62 "Amat florigeram patriam flos de radice Jesse, et libenter inter lilia pascitur flos campi et lilium convallium." (ST. BERNARD, De Annuntiatione Beatae Mariae. Sermo III. PL 183, 396). 

medieval Marian iconography from patristic and theological sources

virginity, the insignia of humility, the preeminence of charity". ${ }^{63}$ Thus linking essentially the Mary's divine motherhood with the absolute fullness of her virtues, St. Bernard designates the Virgin with the nickname of "stem sublime!", in whose apex elevates Jesus until the enthroned God the Father, since "the roots of the [Mary's] humility are plunging into the deep". ${ }^{64}$ For this reason, the abbot of Clairvaux enhances the Savior's Mother with these poetic botanic parallelisms: "Oh plant truly heavenly, more precious than any other, superior to all in holiness! Tree of life, the only one able to bring the fruit of salvation!" 65

Then relating directly the Mary's testimony in her proclamation Magnificat, when she was visiting her cousin Elizabeth -"[God] has their eyes on the humility of his handmaid ${ }^{66}$ - with the passage of the Song of Songs stating that, "resting the king on his bed, my tuberose gave its smell, ${ }^{67}$ St. Bernard asserts that, by being the tuberose a humble plant, which purifies the chest, it was evident to designate the Mary's humility with the name of tuberose, whose smell and beauty found grace before God. ${ }^{68}$

And in another paragraph of his Third Homily on the praise of the Virgin Mary, the saint of Clairvaux insists on these same ideas, in enunciating:

Because, when the king was at his triclinium, the tuberose of the Virgin gave its smell, and the smoke of the incense rose before the presence of his glory, and found pleasure in the Lord's eyes, while the assistants proclaimed: Who is this coming up from the desert, such as a column of smoke, perfumed with myrrh and incense? $^{69}$

63 "Dilectus meus mihi, et ego illi, qui pascitur inter lilia. (...) Apud Mariam utique pascebatur, idque copiosius pro multitudine liliorum. An non lilia virginitatis decus, humilitatis insigne, supereminentia caritatis?" (ST. BERNARD, In Nativitate B. Mariae Virginis Sermo, 17-18. PL 183, 446).

${ }^{64}$ "O Virgo, virga sublimis, in quam sublime verticem sanctum erigis! usque ad Sedentem in throno, usque ad Dominum majestatis. Neque enim id mirum, quoniam in altum mittis radices humilitatis." (St. Bernard, Sermones de Tempore. In Adventu Domini Sermo II, 4. PL 183, 42).

65 "O vere caelestis planta, pretiosior cunctis, sanctior universis! O vere lignum vitae, quod solum fuit dignum portare fructum salutis!” (Ibidem: 42-43).

66 "Quia respexit humilitatem ancillae suae" (Lc 1, 48. En Biblia Sacra iuxta Vulgatam Clementinam, op. cit., p. 1011).

67 "Audi Mariam in Evangelio: Respexit, inquit, humilitatem ancillae suae (Luc. I, 34 48). Audi eamdem in epithalamio: Cum esset rex, inquit, in decubitu suo, nardus mea dedit odorem suum (Cant. I, 11).” (ST. BERnARD, In Assumptione B. Mariae Virginis Sermo IV, 1. PL 183, 428).

68 "Nardus quippe herba humilis est, et pectus purgat: ut manifestum sit humilitatem nardi nomine designari, cujus odor et decor invenerit gratiam apud Deum." (Ibidem).

69 "Nam cum esset Rex in accubitu suo, nardus Virginis dedit odorem suum, et ascendit in conspectu gloriae eius fumus aromatis, et invenit gratum coram oculis Domini, clamantibus qui circumstabant: Quae est ista quae ascendit per desertum, sicut virgula fumi, ex aromatibus myrrae et thuris?" (ST. BERNARD, In laudibus Virginis Matris Homilia III, 2. In Obras completas de San Bernardo. Edición bilingüe promovida por la Conferencia Regional Española de Abades Cistercienses, vol. II. Tratados (2 ${ }^{\circ}$, Madrid, La Editorial Católica, Col. Biblioteca de Autores Cristianos, 1984, p. 642). 

medieval Marian iconography from patristic and theological sources

As implied by the statements exposed here, with these multiple metaphors alluding to flowers and plants Sr. Bernard highlight the unparalleled Mary's fullness of grace and virtues, with special emphasis on her purity, charity, humility of a slave, and her virginal divine motherhood.

The also Cistercian St. Amadeus of Lausanne (c. 1110-1159) ${ }^{70}$ uses in a similar measure some botanical features to praise the Virgin's spiritual and moral qualities, by exposing that she "was exhaling the flower of the virginity, sowed the new field of chastity, offering to the eyes the virtue of humility and showing the marks of sincerity." 71 The holy bishop refers to the Virgin's virtues under the bucolic analogies of white lilies and aromatic flowers. After explaining that the Mary's womb where Christ is engendered is prefigured in the Old Testament with the metaphor of "a heap of wheat surrounded by lilies", ${ }^{72}$ since "the perpetual virginity of the maternal womb is attested by the holy oracles of Scripture", ${ }^{73}$ St. Amadeus wonders: "What are, in effect, the divine words but some lilies that emanate the candor of the purity and spread a pleasant odor of softness?" 74 So for St. Amadeus to compare the Virgin with such beautiful and aromatic flowers means to highlight in her her eminent ethical gifts, in particular her purity, humility, sincerity and perpetual virginity.

For almost the same dates Pierre de (la) Celle (Petrus Cellensius, c. 11151183) qualifies with great lyricism Mary as a rose born of thorns, and beautiful olive in the field, that received the most holy body of her son with the substance of the wheat. ${ }^{75}$

\footnotetext{
${ }^{70}$ On the Mariological thought this Cistercian theologian, see G. BUVAUD, "Introduction". In AMEDEE DE LAUSANNE, Huit homélies mariales (Introduction et Notes par le Chanoine G. Bavaud. Texte latin établi para Dom Jean Deshusses. Traduction par Dom Antoine Dumas), Paris, Les Éditions du Cerf, 1960, p. 7-50, en especial, p. 16-46.

71 "[Maria] Spirabat florem virginitatis, serbat novale castitatis, depingens oculis habitum humilitatis, et praeferens indicium veritatis." (ST. AMADEUS OF LAUSANNE, Homiliae octo felicis memoriae Amedei Episcopi Lausannensis de Laudibus Beatae Mariae, Homilia VII. In AMÉDÉE DE LAUSANNE, Huit homélies mariales, op. cit.: 188).

72 "Felix alvus Mariae, in qua semens ista coaluit. Felix cui dictum est: Venter tuus ut acervus tritici vallatus liliis. Annon ut acervus tritici venter eius, qui grano illo intumuit, quo omnis renatorum seges excrevit?" (ST. AMADEUS OF LAUSANNE, Homiliae octo felicis memoriae Amedei Episcopi Lausannensis de Laudibus Beatae Mariae, Homilia VI. In AMEDEE DE LAUSANNE, Huit homélies mariales, op.cit.: 164).

73 "Liliis namque vallatus dicitur, eo quod uteri materni perennis integritas Scripturae sacris eloquiis approbetur." (Ibidem).

74 "Quid enim sunt aliud divina eloquia nisi quadam lilia emanantia candorem puritatis, et gratum spirantia odorem suavitatis. Hinc est quod Verbum Patris et sapientia, candor lucis aeternae nominatur." (Ibidem).

75 "Sic igitur rosa orta de spinis, sive oliva speciosa in campis, de medulla cedri, et adipe frumenti sanctissimum corpus accepit." (PIERRE DE (LA) CElle (Petrus Cellensius episcopus), Sermo LXIX De Assumptione Beatae Mariae Virginis III. PL 202, 855).
} 

medieval Marian iconography from patristic and theological sources

A century later the Franciscan theologian, mystical and cardinal St. Bonaventure (1218-1274), ${ }^{76}$ in order to highlight the perpetual virginity and purity of the Messiah's immaculate Mother, designates her as white flower and perfumed lily, thanks to her multiple and eminent virtues. Based on so expressive premises, the Franciscan prelate continues his symbolic speech by assuring that "the perfection of the merit in the soul consists in its perfect whiteness, and the Virgin Mary possessed it the most perfectly." "77 In the fervent theologian's opinion, Mary "possessed, in effect, the whiteness of the continence regarding to herself, the whiteness of the innocence regarding to the neighbor and the whiteness of the wisdom regarding to God", to the extent that "continence communicated whiteness to her body, wisdom to her soul and innocence to both." 78 And, after pointing out that "the whiteness of the continence communicated to the Virgin is designated in the whiteness of the flower", St. Bonaventure interprets as a praise to the Mary's perpetual virginity the saying of the Husband over the Wife in the Song of Songs, when he proclaimed: "I am the flower of the field and the lily of the valleys. Like a lily among thorns, so is my friend among the virgins."

The other daughters and virgin are thorns because of the pricks and twinge of lust, not extinct completely in them; but this Virgin was a white and perfumed lily, because she did feel in her no impurities nor carnal corruption, but brightness with all kinds of glow in her thoughts, affections, words, and integrity of her body. ${ }^{80}$

As it can be seen, St. Bonaventure introduces in his Mariological speech these attractive floral metaphors to better illustrate the Mary's virtues, in particular, her innocence, chastity, wisdom, and perpetual virginity, and her full holiness, which makes her entirely immune to any sin.

\footnotetext{
${ }^{76}$ Proclaimed a Doctor of the Church in 1588 by Pope Sixtus V, St. Bonaventure is known as Doctor Seraphicus due to the ardent mysticism and the high poetic tone of his doctrinal writings.

77 “(...) meritum perfectum animae consistit in perfecto eius candore; hic autem fuit perfectissime in Virgine Maria". (St. BonaVenture, De Assumptione B. Virginis Mariae. Sermo V. In Obras de San Buenaventura. Edición bilingüe, Tomo IV. Teología mística, Madrid, La Editorial Católica, Col. Biblioteca de Autores Cristianos, 1963, p. 725).

78 "Fuit namque in Virgine candor continentiae respectu sui, candor innocentiae respectu proximi, candor sapientiae respectu Dei. Continentia candidavit eius carnem; sapientia, mentem; innocentia vero candidavit utramque." (Ibidem: 726).

79 "Candor continentiae Virginis designatur in candore floris; unde de ipsa merito dicit Sponsus Canticorum secundo: Ego flos campi et lilium convallium. Sicut lilium inter spinas, sic amica mea inter filìas." (Ibidem).

80 "Aliae enim filiae et virgines spinae sunt propter aculeos et punctiones concupiscentiae non omnino in eis exstinctae; haec autem fuit lilium candens et redolens quia nihil impuritatis et foeditatis carnalis sensit, sed omnimodum nitorem habuit in cogitatione, affectione, locutione et carnis incorruptione." (Ibidem).
} 
José María SAlVAdor GonZÁLEZ, Sicut lilium inter spinas. Floral metaphors in late medieval Marian iconography from patristic and theological sources

Before we conclude our speech, it is useful to emphasize a very relevant correlation for our purposes. In the first part of the current paper it was mentioned when analyzing a couple of paintings (Pere Serra and Sandro Botticelli) the possible reference of the roses to the devotion of the rosary. On the contrary, in the second part we saw how the Fathers and medieval theologians insisted in relating these roses - and other flowers and plants - to the fullness of grace, the preeminence of glory and the sublimity of Mary's virtues, in particular, her absolute purity and holiness, her perpetual virginity and her divine motherhood. However, far from mutually contradicting each other, both statements are correlated in perfect concordance. After all, the one hundred and fifty Ave Marias that are recited in the rosary do not make but proclaim iteratively, in rhythmic sequence, every one of the great thesis supported by the Fathers and theologians. So:

The Ave Maria, gratia plena Dominus tecum expresses the fullness of grace and the absolute holiness of the Virgin.

The phrase Benedicta tu in mulieribus reveals the preeminence of Mary not only on women and other human, but on the angels and other heavenly creatures.

The expression et benedictus fructus ventris tui, Iesus, complemented with the subsequent praise Sancta Maria, Mater Dei, verbalize her virginal divine maternity and her perpetual virginity.

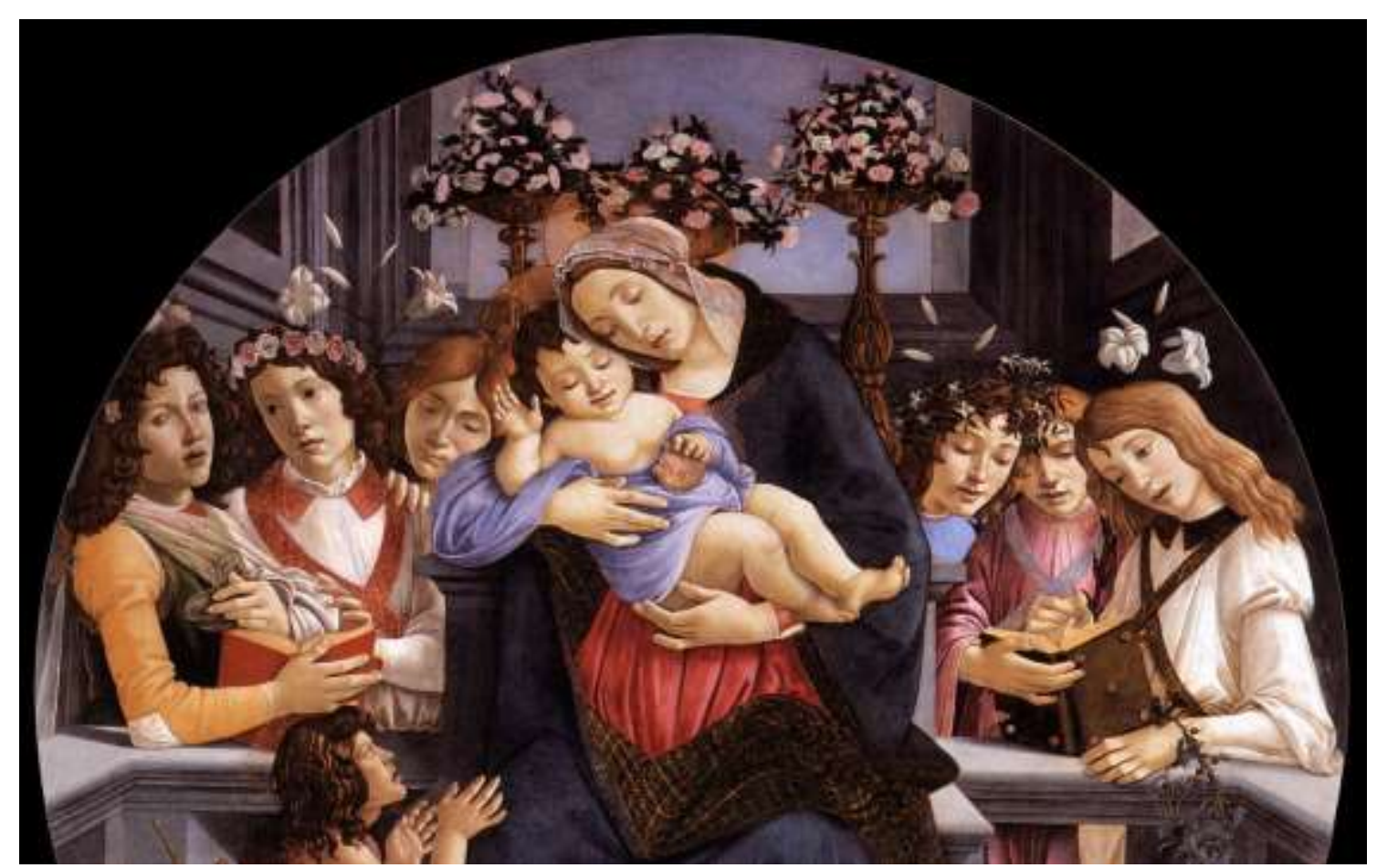

Fig. 11. SANDRO BotTiCELl, Virgen y Niño con seis ángeles y San Juan Bautista, c. 1485 (detalle). Galleria Borghese, Roma. Mitad superior de la Fig. 7.

\section{Conclusions}

As a result of this research on the meaning of the flowers and botanic elements included in the Marian images selected here, it seems reasonable to extract the following corollaries: 
Certain conventional interpretations claim, without argument foundation, that those flowers (in particular, lilies and roses) symbolize any moral quality of Mary, in particular, her virginity or purity, charity or love, as well as her suffering in the Christ's Passion.

Even when acceptable in part, these not totally founded conventions must be justified, complemented and enriched through reliable doctrinal arguments provided by the patristic and theological tradition that gave form and doctrinal legitimacy to Mariology as a whole.

In that order of ideas, we were able to confirm that the various Fathers and theologians use with surprising poetic freedom -through variable selection of specimens and with different exegetical scopes - the botanic equivalency and the metaphors alluding to flowers and plants in order to symbolize the Virgin's moral and spiritual qualities.

So, for example, these ecclesiastical writers sometimes use such floral images to designate some particular virtues of Mary, as her purity, charity or humility.

In other cases they employ these vegetal analogies to symbolize, as an encompassing whole, the Virgin's sublime fullness of grace and virtues, her holiness and her absolute immunity to any sin.

At last, all the aforementioned Fathers and theologians take advantage of the bucolic figures of flowers and plants to signify with particular emphasis on the double essential privilege of Mary -which justifies the other graces and virtues newly mentioned-, namely, her divine motherhood and her perpetual virginity, a double privilege that, in turn, attaches to the Mother of God her preeminence on all other earthly and heavenly creatures, men and angels.

\section{Sources and Bibliography}

\section{Sources}

Álvarez CAmPos, Sergio. Corpus Marianum Patrísticum. Burgos: Aldecoa, 19701981,7 vols.

Amadeus of Lausanne, St., Homiliae octo felicis memoriae Amedei Episcopi Lausannensis de Laudibus Beatae Mariae. En AMEDEE DE LAUSANNE, Huit homélies mariales, Paris, Les Éditions du Cerf, 1960, pp. 52-222

Amadeus of Lausanne, St., Homilia VI. En AmédÉE De Lausanne, Huit homélies mariales, op. cit.: 164.

Amadeus of Lausanne, St., Homilia VII. En Amédée de Lausanne, Huit homélies mariales, op. cit:: 186-188.

AMBroise AUTPERT (attribuited), Epistola IX Ad Paulam et Eustochium De Assumptione beatae Mariae Virginis. PL 30, 122-144.

AMÉDÉE DE LAUSANNE, Huit homélies mariales (Introduction et Notes par le Chanoine G. Bavaud. Texte latin établi para Dom Jean Deshusses. Traduction par Dom Antoine Dumas), Paris, Les Éditions du Cerf, 1960, 240 pp. 
José María SAlvador GonZÁlez, Sicut lilium inter spinas. Floral metaphors in late medieval Marian iconography from patristic and theological sources

Anselm, St., Oratio LX. Ad sanctam Virginem Mariam in Assumptione ejus. PL $158,965$.

Anselm, St., Oratio LIV, Ad sanctam Virginem Mariam. PL 158, 960-961.

ANSELM, ST., Obras completas de San Anselmo (Introducción general y versión castellana por Julián Alameda), Madrid, La Editorial Católica, Col. Biblioteca de Autores Cristianos, 1952-1953, 2 vols.

Bernard, St., Sermones de Tempore. In Adventu Domini Sermo II, 4. PL 183, 4243.

Bernard, St., De Annuntiatione Beatae Mariae. Sermo III. PL 183, 396.

Bernard, St., In Assumptione B. Mariae Virginis Sermo IV, 1. PL 183, 425.

BERNARD, ST., In Nativitate B. Mariae Virginis Sermo, 17-18. PL 183, 437-448.

BERNARD, ST., In laudibus Virginis Matris Homilía III, 2. En Obras completas de San Bernardo. Edición bilingüe promovida por la Conferencia Regional Española de Abades Cistercienses, vol. II. Tratados (2\%), Madrid, La Editorial Católica, Col. BAC, 1984, pp. 638-657.

Bernard, St., San Bernardo. Obras completas, Madrid, La Editorial Católica, Biblioteca de Autores Cristianos, 1953, 2 vols.

BERNARD, St., Obras completas de San Bernardo. Edición bilingüe promovida por la Conferencia Regional Española de Abades Cistercienses, Madrid, La Editorial Católica, Col. Biblioteca de Autores Cristianos, 1949 ss, 6 vols.

Biblia de Jerusalén. Nueva edición revisada y aumentada, Bilbao, Desclée de Brouwer, 1998, 1.895 pp.

Biblia Sacra iuxta Vulgatam Clementinam. Nova editio (logicis partitionibus aliisque subsidiis ornata a Alberto Colunga et Laurentio Turrado). Madrid: La Editorial Católica, Col. Biblioteca de Autores Cristianos, 12 ${ }^{\mathrm{a}}$ edición, 2005, 1.255 pp. + mapas s.p.

Bonaventure, St., Obras de San Buenaventura. Edición bilingüe, Tomo IV. Teología mística, Madrid, La Editorial Católica, Col. Biblioteca de Autores Cristianos, 1963, viii, 787 pp.

Bonaventure, St., De Assumptione B. Virginis Mariae. Sermo V. En Obras completas de San Buenaventura. op. cit., 1947, vol. IV: 894-903.

Celle, Pierre De (LA) (Cellensius, Petrus, episcopus), Sermo LXIX De Assumptione Beatae Mariae Virginis III. PL 202, 851-860.

ANÓNIMOUS WRITER (mid-fifth century), In Nativitatem Domini. En Alvarez CAMPOS 1976, vol. IV/1: 515-516.

ANÓNIMOUS WRITER (sixth century), Sermo Maurinus Ps. Agustini 120. En ÁlVAREZ CAMPOS 1981, vol. VI: 252

Fulbertus of Chartres, St. (Fulbertus CARnotensis episcopus), Sermo IV. De Nativitate Beatissimae Mariae Virginis. PL 141, 320-324.

John Damascene, ST., Homilia in Annuntiationem B.V. Mariae, PG 96: 645-662.

John DAmAsCEne, ST., Homilia In Nativitatem B.V. Mariae. PG 96, 662-681.

Juan Damasceno, SAn, Homilia II In Nativitatem B.V. Mariae. PG 96: 681-698. JOHN DAMASCENE, ST.,

John Damascene, St., Homilia I in Dormitionem B. V. Mariae. PG 96: 699-722.

John Damascene, ST., Homilia II in Dormitionem B.V. Mariae. PG 96: 722-754. 
José María SALVAdOR GonZÁlez, Sicut lilium inter spinas. Floral metaphors in late medieval Marian iconography from patristic and theological sources

Migne, Jacques-Paul (ed.), Patrologiae Cursus Completus, Series Latina, Paris, Garnier, 1844-1864, 221 vols. (This Latin patristic collection is cited with the abreviation PL)

Migne, Jacques-Paul (ed.), Patrologiae Cursus Completus, Series Graeca, Paris, Garnier, 1857-1867, 166 vols. (This Greek patristic collection is cited with the abreviation PG)

PIERRE DE Blois (Petrus Blesensis), Sermo XXXIII. In Assumptione beatae Mariae. PL 207, 662.

Pierre De (la) Celle (Petrus Cellensius episcopus), Sermo LXIX De Assumptione Beatae Mariae Virginis III. PL 202, 855.

Peter Damian, St., Sermones, XLVI. Homilia in Nativitate Beatissimae Virginis Mariae (VIII. Sept.). PL 144, 748-761.

Romanos the Melodist, St. (Romanus Cantor), Hymmus 12, 6. En Álvarez CAMPOS 1979, vol. IV/2: 129-130.

SAntos OTERo, Aurelio de, Los evangelios apócrifos. Salamanca: La Editorial Católica, Biblioteca de Autores Cristianos, 148, 2006, 705 pp.

Venantius Fortunatus, St., Miscel. 8, 3, 25-32. In nomine Domini nostri Iesu Christi et Domnae Mariae Matris eius de virginitate. PL 88, 266 B-267 A. En ÁlVAREZ CAMPOS 1981, vol. VI: 375.

Venantius Fortunatus, St., Caput VII. In laudem sanctae Mariae Virginis et matris Domini. PL 88, 276-284.

\section{Bibliography}

AldamA, José Antonio de, María en la Patrística de los siglos I y II, Madrid, Biblioteca de Autores Cristianos, 1970, 380 pp.

AZCÁRATE Y Ristori, José María de, Arte gótico en España, Madrid, Cátedra, 1990, 498 pp.

BRACONS, Josep \& TRIADÓ, Juan-Ramón, La pintura española. Románico, Gótico, Renacimiento, Barcelona, Carroggio, Col. Arte Carroggio, 2000, 207 pp.

BORCHERT, Till-Holger (dir.), Le siècle de Van Eyck. Le monde méditerranéen et les primitifs flamands: 1430-1530, Gand / Amsterdam, Ludion, 2002.

Buvaud, G., "Introduction". In Amédée de Lausanne, Huit homélies mariales (Introduction et Notes par le Chanoine G. Bavaud. Texte latin établi para Dom Jean Deshusses. Traduction par Dom Antoine Dumas), Paris, Les Éditions du Cerf, 1960, pp. 7-50, en especial, pp. 16-46

DurÁn SANPERE, Agustín \& AINAUd DE LASARTE, Juan, Escultura gótica, Vol. III, Ars Hispaniae, Madrid, Plus Ultra, 1956, 409 pp.

FERNÁNDEZ-LADREDA, Clara, Imaginería medieval mariana, Pamplona, Gobierno de Navarra, Departamento de Educación y Cultura, 1989, 403 pp.

FRIEDLÄNDER, Max Julius, From Van Eyck to Bruegel. Early Netherlandish painting (translated from the German by Marguerite Kay; edited with notes by F.Grossmann), London, Phaidon Press, 1956 (edición original en alemán, 1916)

Gudiol Ricart, José, Pintura gótica, vol. 9 de Ars Hispaniae. Historia Universal del Arte Hispánico, Madrid, Plus Ultra, 1955, 420 pp. 
José María SALVAdOR GonZÁlez, Sicut lilium inter spinas. Floral metaphors in late medieval Marian iconography from patristic and theological sources

Gudiol, Josep \& Alcolea I Blanch, Santiago, Pintura gótica catalana, Barcelona, Ediciones Polígrafa, 1986, 494 pp.

LACARRA DUCAY, María del Carmen, (Coord.), La pintura gótica durante el siglo $X V$ en tierras de Aragón y en otros territorios peninsulares, Zaragoza, Institución Fernando el Católico (CSIC), Col. Actas Arte, 2007, 373 pp.

PÄCHT, Otto, Early Netherlandish Painting from Rogier van der Weyden to Gerard David, New York, Harvey Miller, 1997.

PÄCHT, Otto, Van Eyck and the founders of early Netherlandish painting (Foreword by Arthur Rosenauer; edited by Maria Schmidt-Dengler; translated by David Britt), London, Harvey Miller, 1994.

PANOFSKY, Erwin, Early Netherlandish Painting, Its Origins and Character, Harvard University Press, Cambridge MA 1953.

PANOFSKY, Erwin, Renaissance and Renascences in Western Art, New York, Harper \& Row, 1969.

Post, Chandler Rathfon, A History of Spanish Painting, Milwood, Kraus Reprint, 1976, vol. VII.

SALVADOR GONZÁlez, José María, "Nardus mea dedit odorem suum. Interpretación iconográfica de La Asunción de María con sepulcro florido en el arte italiano bajomedieval a la luz de fuentes patrísticas y teológicas", De Medio Aevo, $\mathrm{n}^{\mathrm{o}}$ 1, enero-junio 2013, Madrid, Universidad Complutense de Madrid, pp. 67-116.

SALVADOR GONZÁLEZ, José María, "Flos de radice Iesse. Aproximación hermenéutica al motivo del lirio en la pintura gótica española de La Anunciación a la luz de fuentes patrísticas y teológicas", Eikón / Imago, 4, julio-diciembre 2013, Madrid, Universidad Complutense de Madrid, pp. 183-222.

SAlVADOR GONZÁLEZ, José María, "Flos campi et lilium convallium. Tercera interpretación del lirio en la iconografía de La Anunciación en el Trecento italiano a la luz de fuentes patrísticas y teológicas", Eikón Imago, $\mathrm{n}^{\mathrm{o}}$ 5, Universidad Complutense de Madrid, enero-junio 2014, pp. 75-96.

SAlvador GonzÁlez, José María, "In virga Aaron Maria ostendebatur. Nueva interpretación del ramo de lirios en La Anunciación gótica española a la luz de fuentes patrísticas y teológicas", Anales de Historia del Arte, n 24, Universidad Complutense de Madrid, 2014, pp. 37-60.

SAUERLÄNDER, Willibald, Gothic sculpture in France, 1140-1270, London, Thames and Hudson, 1970, 527 pp.

SCHILLER, Gertrud, Iconography of Christian Art. Volume I (Translated by Janet Seligman), London, Lund Humphries, 1971, 475 pp.

SCHILLER, Gertrud, Ikonographie der christlichen Kunst. Band 4,2, Maria, Gütersloh, Gütersloher VerlagHaus, 1980, 472 pp.

THEREL, Marie-Louise, Le triomphe de la Vierge-Église. Sources historiques, littéraires et iconographiques (Préface de Michel Mollat du Jourdin, Membre de l'Institut), Paris, Éditions du Centre National de la Recherche Scientifique, 1984, $374 \mathrm{pp}$.

TosCANO, Giuseppe M., Il pensiero cristiano nell'arte, Bergamo, Istituto Italiano d'Arti Grafiche, 1960, 3 vols.

VERDON, Timothy, Maria nell'arte europea (Didascalie a cura di Filippo Rosi), 
José María SAlVAdor GonZÁLEZ, Sicut lilium inter spinas. Floral metaphors in late medieval Marian iconography from patristic and theological sources

Milano, Electa, 2004, 227 pp.

Vloberg, Maurice, La Vierge et l'Enfant dans l'art français, Paris: Arthaud, 1954 (1933), 323 pp.

Williamson, Paul, Escultura gótica, 1140-1300, Madrid, Cátedra, Manuales Arte Cátedra, 1997, 457 pp. 